https://doi.org/10.5194/amt-2020-252

Preprint. Discussion started: 13 July 2020

(c) Author(s) 2020. CC BY 4.0 License.

\title{
Development of a chemical ionization mass spectrometry system for measurement of
} atmospheric $\mathrm{OH}$ radical

3 Wei Pu${ }^{1 *}$, Zhouxing Zou ${ }^{1 *}$, Weihao Wang ${ }^{1}$, David Tanner ${ }^{2}$, Zhe Wang ${ }^{3}$, and Tao Wang ${ }^{1}$

$4 \quad{ }^{1}$ Department of Civil and Environmental Engineering, The Hong Kong Polytechnic University, 5 Hong Kong, China

$6 \quad{ }^{2}$ School of Earth and Atmospheric Sciences, Georgia Institute of Technology, Atlanta, USA

$7 \quad{ }^{3}$ Division of Environment and Sustainability, The Hong Kong University of Science and

8 Technology, Hong Kong, China

9

10 Correspondence to: Tao Wang (cetwang @ polyu.edu.hk)

11

*These authors contributed equally to this work 
1 Abstract. The hydroxyl radical $(\mathrm{OH})$ is the most important oxidant in the atmosphere and plays

2 a central role in tropospheric chemistry. Ambient $\mathrm{OH}$ is extremely difficult to measure because

3 of its low concentration and high reactivity. We have developed and optimized a chemical

4 ionization mass spectrometry (CIMS) system to measure OH based on ion-assisted mass

5 spectrometry. A calibration unit was developed based on chemical actinometry to convert

6 detected signals to $\mathrm{OH}$ concentration. Different types of ion sources $\left({ }^{210} \mathrm{Po}\right.$ and corona source $)$

7 and scavenger gases (propane, $\mathrm{C}_{3} \mathrm{~F}_{6}$, and $\mathrm{NO}_{2}$ ) were compared. Radioactive ion source $\left({ }^{210} \mathrm{Po}\right.$

8 foils) was chosen for lower detection limits, and propane was selected for high elimination

9 efficiency and the negligible influence on the signal stability. The sensitivity of the CIMS instrument to $\mathrm{OH}$ radicals is influenced by the efficiencies of titration reaction, ion conversion, and ion transmission. Through adjusting their efficiencies by changing the flow rates and voltages, optimal sensitivity was determined. The background noise from $\mathrm{OH}$ interferences was reduced by adjusting the flow rate of scavenger gas. The CIMS system achieved a detection limit of $\sim 0.15 \times 10^{6}$ molecules $\mathrm{cm}^{-3}$ ( signal/noise=2). The CIMS was then taken out to measure ambient $\mathrm{OH}$ radicals at an urban site in Hong Kong in April 2019. An obvious diurnal pattern of $\mathrm{OH}$ radicals was observed, with the highest concentration of $\sim 6 \times 10^{6}$ molecules $\mathrm{cm}^{-3}$ at midday and the lowest concentration of $\sim 0.25 \times 10^{6}$ molecules $\mathrm{cm}^{-3}$ at night, with an overall accuracy of about $\pm 51 \%$. The results demonstrated the capability of our CIMS for $\mathrm{OH}$ measurements on clear days. The tests and results from our study provide a useful reference to other researchers who wish to develop and apply the CIMS technique to measure $\mathrm{OH}$ and other chemicals. 


\section{Introduction}

2 The hydroxyl radical $(\mathrm{OH})$ is the most important atmospheric cleansing agent and is

3 responsible for the degradation and removal of most of trace gases (Crosley, 1997). In regions

4 strongly affected by anthropogenic activities, reactions of $\mathrm{OH}$ with volatile organic compounds

5 (VOCs) and carbon monoxide (CO) lead to the formation of organic peroxy $\left(\mathrm{RO}_{2}\right)$ and

6 hydroperoxyl $\left(\mathrm{HO}_{2}\right)$ radicals. They react with $\mathrm{NO}$ to form nitrogen dioxide $\left(\mathrm{NO}_{2}\right)$, producing

7 ozone $\left(\mathrm{O}_{3}\right)$ (e.g., Hofzumahaus et al., 2009). The reactions of $\mathrm{OH}$ with $\mathrm{NO}_{2}$ and sulfur dioxide

$8\left(\mathrm{SO}_{2}\right)$ and the self- and cross-reactions of $\mathrm{RO}_{2}$ and $\mathrm{HO}_{2}$ transform the primary pollutants into

9 low-vapor pressure gas molecules such as nitric acid $\left(\mathrm{HNO}_{3}\right)$, sulfuric acid $\left(\mathrm{H}_{2} \mathrm{SO}_{4}\right)$, and highly oxidized organic molecules (HOMs) (Lu et al., 2012). In addition, the reaction with $\mathrm{OH}$ is the main removal pathway of methane, which is the third most important greenhouse gas.

12 Therefore, $\mathrm{OH}$ plays key roles in major environmental issues such as photochemical pollution, acid rain, haze, and climate change (Kulmala et al., 2004; Wang et al., 2017; Calvert et al.,

14 1985; Lu et al., 2019).

The importance of $\mathrm{OH}$ in tropospheric chemistry was first recognized by Levy (1971). Since then, concerted efforts have been made to develop techniques to measure $\mathrm{OH}$ in the atmosphere (Heard and Pilling, 2003). However, the low concentration, high reactivity, and short lifetime (<1 s) of $\mathrm{OH}$ make itself enormously difficult to be detected and quantified. The low concentration requires high sensitivities and small interferences in the instruments; the high reactivity demands a small loss in the ambient sampling, and the short lifetime requires measurement at a high temporal-spatial resolution. It is a huge challenge to meet all of these requirements by a measurement system (Lu et al., 2019).

During the past decades, three major techniques have been developed for in-situ $\mathrm{OH}$ measurements: differential optical absorption spectroscopy (DOAS) (Wennberg et al., 1990), 
1 laser-induced fluorescence (LIF) (Perner et al., 1976), and chemical ionization mass

2 spectrometry (CIMS) (Eisele and Tanner, 1991). DOAS and LIF techniques directly measure

$3 \mathrm{OH}$ based on spectroscopic methods. The major advantage of DOAS is that it is self-calibrating

4 via the well-known Beer-Lambert law and thus does not require to separate a calibration device

5 (Heard and Pilling, 2003). DOAS often serves as a primary standard for comparisons with other

6 measurement techniques. However, the application of DOAS to the measurement of ambient

$7 \mathrm{OH}$ is limited due to the interferences from other atmospheric constituents (Heard and Pilling,

8 2003). LIF measures $\mathrm{OH}$ by using pulsed $308 \mathrm{~nm}$ single photon excitation of $\mathrm{OH}$ at low

9 pressure with temporally delayed detection of the resonant $\mathrm{OH}$ fluorescence (known as fluorescence assay by gas expansion, FAGE) (Holland et al., 1995), and it requires calibration. The LIF technique has the advantages of direct excitation of $\mathrm{OH}$ and good selectivity and sensitivity (Heard and Pilling, 2003). Unlike DOAS and LIF, the CIMS technique measures $\mathrm{OH}$ indirectly based on the ion-assisted mass spectrometry method. It employs a chemical reaction scheme that $\mathrm{OH}$ is firstly titrated into $\mathrm{H}_{2} \mathrm{SO}_{4}$ and subsequently measured by a specific chem-ionization method (Eisele and Tanner, 1991). CIMS has fewer interference and higher sensitivity compared to either DOAS or LIF techniques for $\mathrm{OH}$ measurement because of the higher collection efficiency of ions than photons (Heard and Pilling, 2003). As a result, CIMS processes the lowest detection limit for ambient $\mathrm{OH}$ measurement among the three techniques (Heard and Pilling, 2003).

LIF has been the most widely used technique for $\mathrm{OH}$ measurement in laboratory and field studies (Stone et al., 2012). However, some LIF instruments may suffer from interferences in environments of rich VOCs and poor NOx. Previous field measurements by LIF in forested regions have observed $\mathrm{OH}$ concentrations that are three to five times higher than those predicted by models with presently known OH sources and sinks (McKeen et al., 1997; Lelieveld et al. 2008; Hofzumahaus et al., 2009; Whalley 2011; Lu et al. 2012; Mao et al. 2012; 
$1 \quad$ Novelli et al. 2014; Feiner et al. 2016; Tan et al. 2017). The disagreements were first attributed

2 to the existence of an unknown source of $\mathrm{OH}$ in VOC-rich environment (Peeters et al., 2009;

3 Hofzumahaus et al., 2009), whereas later studies found positive artifacts in some LIF

4 instruments in such environments (Mao et al. 2012; Novelli et al. 2014; Feiner et al. 2016; Liu

5 et al. 2018). For example, Mao et al. (2012) attributed 40-60\% observed OH signal at a

6 California forest to interference in their LIF by using a chemical method to remove the

7 interference. Recently, Liu et al. (2018) inferred the equivalent $\mathrm{OH}$ concentrations from

8 measurements of isoprene and its oxidation products over Amazon and found that the inferred

$9 \mathrm{OH}$ concentrations compared well with the simulated results. On the other hand, other groups did not find evidence of the positive bias in their LIF systems, which have different design and configurations, continued to attribute the model underestimated $\mathrm{OH}$ to the presence of $\mathrm{OH}$ unknown source(s) at their study sites (Whalley 2011; Stone et al., 2012; Fuchs et al.2012; Lu et al. 2012; Tan et al. 2017). It is highly desirable to deploy an alternative technique to reexamine the $\mathrm{OH}$ issue in forested regions.

The CIMS technique for measuring $\mathrm{OH}$ was first developed at Georgia Institute of Technology by Eisele and Tanner (1991). The system was further improved at National Center for Atmospheric Research by reducing wall reactions (Eisele and Tanner., 1993), by reducing the background signal (Tanner and Eisele., 1995) and by developing a better calibration system (Tanner et al., 1997). Mauldin et al. (1998) modified the CIMS for measurement at an aircraft platform during the First Aerosol Characterization Experiment (ACE1), and Edwards et al. (2003) further upgraded the calibration system. Based on the design of Tanner et al. (1997), another two CIMS instruments were developed at the Meteorological Observatory Hohenpeissenberg, Germany, by Berresheim et al. (2000) and at the National University of Ireland Galway by Berresheim et al. (2013). Kukui et al. (2008) developed a new version of 
1 the CIMS instrument at the Centre National de la Recherche Scientifique (CNRS), France,

2 which allowed for $\mathrm{OH}$ measurements in a moderately polluted atmosphere.

3 We describe here a new CIMS system that has been tested and optimized at The Hong Kong

4 Polytechnic University (PolyU). The instrument was built at THS, Inc (Atlanta, Georgia) with

5 the same design as the CIMS from the group of Eisele and Tanner. The measurement principles,

6 configurations of the CIMS instrument, and a calibration unit are described in detail. Different

7 scavenger gases, ion sources, and primary ions detection was compared. In addition, the

8 sensitivity and noise of the CIMS instrument to $\mathrm{OH}$ radicals were tested by adjusting the flow

9 rates and voltages. Accordingly, their optimal settings were derived. Finally, the test result of ambient $\mathrm{OH}$ measurement was presented. These results provide detailed technical information

11 for other researchers who wish to apply the CIMS for ambient $\mathrm{OH}$ measurement. To our

12 knowledge, this instrument is the first $\mathrm{OH}$ measuring CIMS in Asia.

\section{Measurement principles}

The measurement of hydroxyl radical $(\mathrm{OH})$ in this study was made with a chemical ionization mass spectrometry (CIMS) technique, which has been described previously (Tanner et al., 1997; Sjostedt et al., 2007). Briefly, the ambient $\mathrm{OH}$ is titrated to $\mathrm{H}_{2} \mathrm{SO}_{4}$ by adding $\mathrm{SO}_{2}$ into the sample air flow, which initiates the following reaction sequence in the presence of oxygen and water vapor:

$$
\mathrm{OH}+\mathrm{SO}_{2}+\mathrm{M} \rightarrow \mathrm{HSO}_{3}+\mathrm{M}
$$


1 However, $\mathrm{H}_{2} \mathrm{SO}_{4}$ in the atmosphere also contributes to the total $\mathrm{H}_{2} \mathrm{SO}_{4}$ concentration. To solve

2 the problem, a scavenger gas is periodically added into the sample air flow to remove $\mathrm{OH}$

3 radicals. Then, $\mathrm{H}_{2} \mathrm{SO}_{4}$ produced from the reaction of $\mathrm{OH}$ and $\mathrm{SO}_{2}$ can be obtained:

4

$$
\left[\mathrm{H}_{2} \mathrm{SO}_{4}\right]_{\mathrm{OH}}=\left[\mathrm{H}_{2} \mathrm{SO}_{4}\right]_{\mathrm{TS}}-\left[\mathrm{H}_{2} \mathrm{SO}_{4}\right]_{\mathrm{BS}}
$$

$\left[\mathrm{H}_{2} \mathrm{SO}_{4}\right]_{\mathrm{TS}}$ and $\left[\mathrm{H}_{2} \mathrm{SO}_{4}\right]_{\mathrm{BS}}$ are $\mathrm{H}_{2} \mathrm{SO}_{4}$ concentrations with and without adding scavenger gas, respectively.

Apart from the interference from the pre-existing $\mathrm{H}_{2} \mathrm{SO}_{4}$, the reactions of NO with peroxy radicals $\left(\mathrm{HO}_{2}+\mathrm{RO}_{2}\right)$, whose daytime concentrations are typically 1-2 orders of magnitude of $\mathrm{OH}$, can produce $\mathrm{OH}$ in the sample flow (Sjostedt et al., 2007):

$$
\begin{aligned}
& \mathrm{RO}_{2}+\mathrm{NO}+\mathrm{O}_{2} \rightarrow \mathrm{R}^{\prime} \mathrm{CHO}+\mathrm{HO}_{2}+\mathrm{NO}_{2} \\
& \mathrm{HO}_{2}+\mathrm{NO} \rightarrow \mathrm{OH}+\mathrm{NO}_{2}
\end{aligned}
$$

Reaction 2 can also produce $\mathrm{HO}_{2}$ radicals as intermediate products. To reduce the positive bias from Reaction 5, another scavenger gas is added into the sample flow after $\mathrm{SO}_{2}$ to scavenge recycled $\mathrm{OH}$ radicals.

The $\mathrm{H}_{2} \mathrm{SO}_{4}$ is then converted into $\mathrm{HSO}_{4}^{-}$by chemical ionization in reaction with the $\mathrm{NO}_{3}^{-}$ primary reactant ions:

$$
\mathrm{H}_{2} \mathrm{SO}_{4}+\mathrm{NO}_{3}^{-} \cdot\left(\mathrm{HNO}_{3}\right)_{\mathrm{m}} \cdot\left(\mathrm{H}_{2} \mathrm{O}\right)_{\mathrm{n}} \rightarrow \mathrm{HSO}_{4}^{-} \cdot\left(\mathrm{HNO}_{3}\right)_{\mathrm{m}}\left(\mathrm{H}_{2} \mathrm{O}\right)_{\mathrm{n}}+\mathrm{HNO}_{3}
$$

$\mathrm{NO}_{3}^{-} \cdot\left(\mathrm{HNO}_{3}\right)_{\mathrm{m}} \cdot\left(\mathrm{H}_{2} \mathrm{O}\right)_{\mathrm{n}}$ are cluster ions of $\mathrm{NO}_{3}^{-}$reactant ions with neutral $\mathrm{HNO}_{3}$ and/or $\mathrm{H}_{2} \mathrm{O}$ molecules, with $\mathrm{m}$ and $\mathrm{n}$ mostly of 0-2 and 0-3 (Berresheim et al., 2000). The $\mathrm{NO}_{3}^{-} \cdot\left(\mathrm{HNO}_{3}\right)_{\mathrm{m}}$. $\left(\mathrm{H}_{2} \mathrm{O}\right)_{n}$ cluster ions are generated by the reaction of $\mathrm{HNO}_{3}$ vapor with electrons (Fehsenfeld et al., 1975):

$$
\mathrm{HNO}_{3}+\mathrm{e}^{-} \rightarrow \mathrm{NO}_{2}^{-}+\mathrm{OH}
$$




$$
\mathrm{NO}_{3}^{-}+\left(\mathrm{HNO}_{3}\right)_{\mathrm{m}}+\left(\mathrm{H}_{2} \mathrm{O}\right)_{\mathrm{n}}+\mathrm{M} \rightarrow \mathrm{NO}_{3}^{-} \cdot\left(\mathrm{HNO}_{3}\right)_{\mathrm{m}} \cdot\left(\mathrm{H}_{2} \mathrm{O}\right)_{\mathrm{n}}+\mathrm{M}
$$

3 Where $\mathrm{e}^{-}$is emitted from an ion source. The $\mathrm{OH}$ radical (artificial $\mathrm{OH}$ ) formed from primary

4 ion creation (Reaction 7) is not desirable and regards as noise signal, see details in Section

5 5.4.3. The $\mathrm{NO}_{3}^{-} \cdot\left(\mathrm{HNO}_{3}\right)_{\mathrm{m}} \cdot\left(\mathrm{H}_{2} \mathrm{O}\right)_{\mathrm{n}}$ and $\mathrm{HSO}_{4}^{-} \cdot\left(\mathrm{HNO}_{3}\right)_{\mathrm{m}}\left(\mathrm{H}_{2} \mathrm{O}\right)_{\mathrm{n}}$ are subsequently

6 dissociated by the collisional dissociation chamber (CDC):

7

8

9 The $\mathrm{OH}$ is finally detected by a mass spectrometer system as $\mathrm{HSO}_{4}^{-}$at $97 \mathrm{~m} / \mathrm{z}$.

\section{CIMS system}

Figure 1 shows the schematic of our CIMS system, which consists of two parts including a sample inlet system and a mass spectrometer system. The sample inlet system has two regions: chemical titration region and chemical ionization region. The chemical titration region is where $\mathrm{H}_{2} \mathrm{SO}_{4}$ formed by the titration reaction of $\mathrm{OH}$ and $\mathrm{SO}_{2}$. Chemical ionization region is for converting $\mathrm{H}_{2} \mathrm{SO}_{4}$ into $\mathrm{HSO}_{4}^{-}$ion cluster. The mass spectrometer system consists of three parts including a collisional dissociation chamber (CDC), an ion guide chamber (IGC), and an ion detection chamber (IDC). $\mathrm{HSO}_{4}^{-}$ion cluster is dissociated to $\mathrm{HSO}_{4}^{-}$in the $\mathrm{CDC}$, then refocused in the IGC and finally detected in the IDC.

\subsection{Sample inlet}

During $\mathrm{OH}$ measurements, sample air at ambient temperature and pressure is first drawn into a $5 \mathrm{~cm}$ diameter, $32 \mathrm{~cm}$ long stainless-steel tube by a blower. The flow velocity is measured manually using a pitot. A scoop is attached to the front of the stainless-steel tube for turbulence reduction. The central part of the flow is then drawn through a $1.6 \mathrm{~cm}$ diameter stainless steel 
1 inlet into the chemical titration region with the flow rate being determined by a mass flow

2 controller (MKS, MFC company). The excess flow is vented back into the atmosphere via an

3 inlet blower.

\section{$4 \quad$ 3.1.1 Chemical titration region}

5 The chemical titration region in Figure 1 is equipped with two pairs of opposed stainless steel 6 needle injectors. The first (front injectors) pair is installed at a $69 \mathrm{~mm}$ distance from the tube.

7 The distances between the first and second (rear injectors) pairs are $25.8 \mathrm{~mm}$. To measure $\mathrm{OH}$

8 radicals, $\mathrm{SO}_{2}$ is continuously added into the sample flow from the front injectors to titrate $\mathrm{OH}$

9 into $\mathrm{H}_{2} \mathrm{SO}_{4}$ (Reactions 1-3). In this study, we used ${ }^{32} \mathrm{SO}_{2}$ to titrate $\mathrm{OH}$, and the purity of $\mathrm{SO}_{2}$ is

$10 \quad 0.9$ vol. $\%$.

11 As discussed above, atmospheric $\mathrm{H}_{2} \mathrm{SO}_{4}$ can contribute background signals for $\mathrm{OH}$

12 measurements. Therefore, another flow is added through a zero-dead space four-way

13 electrically operated valve, which is automatically switched the injection positions of

14 scavenger gas and pure $\mathrm{N}_{2}$ every 3 minutes (see the pulsed flow in Figure 1 ). When the

15 scavenger gas is added through the front injectors to the sample flow, $\mathrm{N}_{2}$ is switched through the rear injectors. CIMS is then running in background mode. Under this condition, atmospheric $\mathrm{OH}$ simultaneously reacts with $\mathrm{SO}_{2}$ and the scavenger gas, with the reaction of $\mathrm{OH}$ with scavenger gas being much faster than $\mathrm{SO}_{2}$. This configuration produces background signal (BS) from the interferences of atmospheric $\mathrm{H}_{2} \mathrm{SO}_{4}$ and the ion source, with negligible contribution from atmospheric $\mathrm{OH}$. When the scavenger gas and $\mathrm{N}_{2}$ are switched into the sample flow through the rear and front injectors, respectively, CIMS is running in the signal mode. Atmospheric $\mathrm{OH}$ is all titrated by $\mathrm{SO}_{2}$ and the total signal (TS) is produced. In addition,

23 another flow of scavenger gas is added continuously into the sample flow through the rear injectors to scavenge $\mathrm{OH}$ radicals generated from Reaction 5. The $\mathrm{OH}$ concentration is obtained 
1 from the ratio of the difference between the total signal and the background signal to the

2 primary ion $\left(\mathrm{NO}_{3}{ }^{-}\right)$signal. (Tanner and Eisele, 1995):

3

$$
[\mathrm{OH}]=\frac{1}{\mathrm{C}} \times \frac{\left\{\mathrm{HSO}_{4}^{-}\right\}_{\mathrm{TS}}-\left\{\mathrm{HSO}_{4}^{-}\right\}_{\mathrm{BS}}}{\left\{\mathrm{NO}_{3}^{-}\right\}}
$$

4

7 The sample flow through the chemical titration region is then drawn into the chemical

Where square brackets and text braces are used to denote concentrations and signal counts, respectively. $\mathrm{C}$ is the calibration factor.

\subsubsection{Chemical ionization region}

ionization region and mixed with the sheath gas (Figure 1). The sheath gas flow is continuously drawn into the chemical ionization region through the annular space between the $3.5 \mathrm{~cm}$ o.d. and $1.2 \mathrm{~cm}$ o.d. stainless steel tubes by a diaphragm pump (KNF-813). These tubes are concentric with the downstream end of the chemical titration region. The sheath gas is produced by a zero-air generator (Thermo Electron Corporation, Model 111) attached with active charcoal and silica gel. Therefore, particles, $\mathrm{SO}_{2}, \mathrm{NO}_{\mathrm{x}}$ and other trace gases are removed effectively from the sheath gas. Before entering the ionization region, $\mathrm{HNO}_{3}$ vapor and the scavenger gas are added continuously to the sheath gas. The $\mathrm{HNO}_{3}$ vapor is obtained by $\mathrm{N}_{2}$ carrier gas flow passing through the headspace of a reservoir of concentrated liquid $\mathrm{HNO}_{3}$. When $\mathrm{HNO}_{3}$ doped sheath gas passes through the ion source (Figure 1), $\mathrm{NO}_{3}^{-} \cdot\left(\mathrm{HNO}_{3}\right)_{\mathrm{m}}$. $\left(\mathrm{H}_{2} \mathrm{O}\right)_{\mathrm{n}}$ reactant ions are produced by the reaction of $\mathrm{HNO}_{3}$ and electrons (Reactions 7-9).

The $\mathrm{NO}_{3}^{-} \cdot\left(\mathrm{HNO}_{3}\right)_{\mathrm{m}} \cdot\left(\mathrm{H}_{2} \mathrm{O}\right)_{\mathrm{n}}$ reactant ions from the sheath gas then react with $\mathrm{H}_{2} \mathrm{SO}_{4}$ molecules from the sample air to form $\mathrm{HSO}_{4}^{-} \cdot\left(\mathrm{HNO}_{3}\right)_{\mathrm{m}}\left(\mathrm{H}_{2} \mathrm{O}\right)_{\mathrm{n}}$ cluster ions in the chemical ionization region according to Reaction 6. Voltages are added on the sample and sheath flow tubes to produce an electrical field to force the $\mathrm{NO}_{3}^{-} \cdot\left(\mathrm{HNO}_{3}\right)_{\mathrm{m}} \cdot\left(\mathrm{H}_{2} \mathrm{O}\right)_{\mathrm{n}}$ reactant ions to the center of the chemical ionization region and enhance the interaction of reactant ions with 
$1 \mathrm{H}_{2} \mathrm{SO}_{4}$. This effectively increases the signal levels and improves the sensitivity for $\mathrm{OH}$ measurements.

3 The total flow (Figure 1) is then exhausted at the end of the chemical ionization region through

4 diaphragm pumps (Thomas, SK-668) and controlled by an MFC. To prevent the $\mathrm{HNO}_{3}$ vapor

5 from corroding the pump and MFC and polluting the ambient air, the exhaust flow is first

6 filtered through active charcoal cartridges and then vented back into the atmosphere at a

7 distance of $>10 \mathrm{~m}$ from the sampling point. A small portion of the total flow is finally drawn

8 into the mass spectrometer system through a 101.6 um diameter pinhole. The air molecules,

9 especially $\mathrm{H}_{2} \mathrm{O}$ molecules may form higher-order clusters upon adiabatic expansion and cool in the vacuum mass spectrometer system (Berresheim et al., 2000). To reduce this influence, a small counterflow of $\mathrm{N}_{2}$ buffer gas is added on the atmospheric pressure side of the pinhole (Figure 1). And voltages are added at the positions of $\mathrm{N}_{2}$ buffer and pinhole to force the ions into the mass spectrometer system.

\subsection{Mass spectrometer system}

The mass spectrometer system is separated into three differentially pumped chambers with two adjacent chambers being connected through a $4 \mathrm{~mm}$ pinhole (Figure 1). The first chamber behind the pinhole is a collisional dissociation chamber (CDC). The pressure of the CDC is typically maintained at around $0.5 \mathrm{hPa}$ through a drag pump (Adixen, MDP 5011) and a scroll pump (Agilent Technologies, IPD-3). The CDC has a high ion kinetic energy (i.e. high electric field to number density ratio), and most of the entered cluster ions (e.g. $\mathrm{HSO}_{4}^{-}$. $\left(\mathrm{HNO}_{3}\right)_{\mathrm{m}}\left(\mathrm{HO}_{2}\right)_{\mathrm{n}}$ and $\left.\mathrm{NO}_{3}^{-} \cdot\left(\mathrm{HNO}_{3}\right)_{\mathrm{m}} \cdot\left(\mathrm{HO}_{2}\right)_{\mathrm{n}}\right)$ are dissociated in the $\mathrm{CDC}$ through Reactions 10-11.

The second chamber is an octopole ion guide high vacuum chamber (IGC). In this chamber, the pressure is maintained at about $1.3 \times 10^{-3} \mathrm{hPa}$ through a turbo molecular pump (Agilent 
1 Technologies, TwisTorr 304 Fs) and the same scroll pump. Here, the ions from the CDC are

2 refocused by an octopole ion guide and transported to the third chamber.

3 The third chamber (IDC) contains a quadrupole mass filter and detector with attached signal

4 amplifier electronics. The mass-selected ions of the quadrupole are amplified and detected by

5 a channeltron ion multiplier, and then counted based on standard techniques (Sjostedt et al.,

6 2007). This chamber maintains a pressure of about $2.6 \times 10^{-5} \mathrm{hPa}$ through another turbo

7 molecular pump (Agilent Technologies, TwisTorr 304 Fs) and the same scroll pump.

8 4. Calibration

\section{$9 \quad 4.1$ Calibration principle}

10 The calibration of CIMS (Figure 2a) is achieved by controlled concentrations of $\mathrm{OH}$ radicals,

11 which is produced through photolysis of water vapor by $184.9 \mathrm{~nm}$ light (Tanner and Eisele,

12

13

14

15 1995):

$$
\mathrm{H}_{2} \mathrm{O}+h v(184.9 \mathrm{~nm}) \rightarrow \mathrm{OH}+\mathrm{H}
$$

$$
\mathrm{H}+\mathrm{O}_{2}+\mathrm{M} \rightarrow \mathrm{HO}_{2}+\mathrm{M}
$$

The calibration factor $\mathrm{C}$ is then determined based on the produced $\mathrm{OH}$ concentrations and detected signals of $\mathrm{HSO}_{4}^{-}$and $\mathrm{NO}_{3}^{-}$according to Equation 2.

\subsection{Calibration unit}

Figure 2 shows the main components of the calibration unit. The length of the cuboid stainless steel tube is $52 \mathrm{~cm}$ with $1.6 \mathrm{~cm}$ side length. A high-precision capacitance humidity measurement hygrometer (Vaisala, HMP100) is connected at the front of the tube and is used to measure the temperature $T$ and dew point temperature $T_{d}$ of the mixed air. The optical elements for illumination are mounted at the end of the tubes (air outlet side) to minimize the 
1 influence of wall loss during calibration. The optical elements consist of a Pen Ray mercury

2 lamp (Analytik Jena, UVP Pen Ray) and a bandpass filter. The bandpass filter blocks most of

3 the photons emitted from the $\mathrm{Hg}$ lamp except those at $184.9 \mathrm{~nm}$. A small $\mathrm{N}_{2}$ flow is purged to

4 prevent UV absorption and the formation of ozone (Kukui et al., 2008). Finally, the transmitted

5 light enters the tube and photolyzes water vapor to produce $\mathrm{OH}$ radicals according to Reaction

6 12. The mixing ratio of water vapor in the air flow is controlled through the mix of the dry

7 synthetic air and humidity air from a water bubbler.

\section{$8 \quad 4.3$ Calibration quantification}

\section{$9 \quad$ 4.3.1 OH quantification}

10 The concentrations of $\mathrm{OH}$ radicals produced from the water vapor photolysis reaction can be

11 described as follow:

$12[\mathrm{OH}]=I \times t \times \sigma_{\mathrm{H}_{2} \mathrm{O}} \times \phi_{\mathrm{H}_{2} \mathrm{O}} \times\left[\mathrm{H}_{2} \mathrm{O}\right]$

13 Where $I$ and $t$ are the photon intensity (unit: photons $\mathrm{s}^{-1} \mathrm{~cm}^{-2}$ ) and the reaction time of $\mathrm{H}_{2} \mathrm{O}$ photolysis, respectively. $[\mathrm{OH}]$ and $\left[\mathrm{H}_{2} \mathrm{O}\right]$ are the concentrations of $\mathrm{OH}$ radicals and water vapor, respectively, $\sigma_{\mathrm{H}_{2} \mathrm{O}}$ is the photolysis cross-section of water vapor at $184.9 \mathrm{~nm}\left(7.22 \times 10^{-20} \mathrm{~cm}^{2}\right.$, Cantrell et al., 1997 ) and $\phi_{\mathrm{H}_{2} \mathrm{O}}$ represents the photolysis quantum yield, which is assumed to be 1.0 at $184.9 \mathrm{~nm} .\left[\mathrm{H}_{2} \mathrm{O}\right]$ is calculated according to the temperature $(\mathrm{T})$, saturated water vapor pressure $\left(P_{\mathrm{H}_{2} \mathrm{O}}^{\circ}\right)$ and relative humidity $(\mathrm{RH})$ of the mixed air flow:

$$
\left[\mathrm{H}_{2} \mathrm{O}\right]=\frac{R H \times P_{\mathrm{H}_{2} \mathrm{O}}^{\circ} \times 100}{R T} \times N A
$$

$\mathrm{R}$ is the ideal law constant and NA is the Avogadro's number. $I$ and $t$ are obtained as a combined product It .

\subsubsection{It quantification}


1 The combined product It is obtained based on the chemical actinometry method (Figure $2 b$ ).

2 This method measures $\mathrm{NO}_{x}$ generated from $\mathrm{N}_{2} \mathrm{O}$ photolysis with the same calibration unit under

3 the same condition of the CIMS calibration. Since $\mathrm{N}_{2} \mathrm{O}$ photolysis generates $\mathrm{NO}_{\mathrm{x}}$ through the

4 illumination of the UV light with the same photon intensity as the $\mathrm{H}_{2} \mathrm{O}$ photolysis, product $I t$

5 can be determined by measured $\mathrm{NO}_{\mathrm{x}}$ and $\mathrm{N}_{2} \mathrm{O}$ mixing ratios (Edwards et al., 2003).

6 Briefly, high purity $\mathrm{N}_{2} \mathrm{O}(99.9 \%)$ mixed with dry $\mathrm{N}_{2}$ or dry synthetic gas flows into the

7 calibration unit. The photolysis of $\mathrm{N}_{2} \mathrm{O}$ leads to the formation of $\mathrm{NO}_{\mathrm{x}}$ in the presence of oxygen

8 and nitrogen through the following reactions (Edwards et al., 2003):

9

10

11

12

13

$$
\begin{aligned}
& \mathrm{N}_{2} \mathrm{O}+h v(184.9 \mathrm{~nm}) \rightarrow \mathrm{N}_{2}+\mathrm{O}\left({ }^{1} \mathrm{D}\right) \\
& \mathrm{O}\left({ }^{1} \mathrm{D}\right)+\mathrm{O}_{2} \rightarrow \mathrm{O}\left({ }^{3} \mathrm{P}\right)+\mathrm{O}_{2} \\
& \mathrm{O}\left({ }^{1} \mathrm{D}\right)+\mathrm{N}_{2} \rightarrow \mathrm{O}\left({ }^{3} \mathrm{P}\right)+\mathrm{N}_{2} \\
& \mathrm{O}\left({ }^{3} \mathrm{P}\right)+\mathrm{O}_{2}+\mathrm{M} \rightarrow \mathrm{O}_{3}+\mathrm{M} \\
& \mathrm{O}\left({ }^{1} \mathrm{D}\right)+\mathrm{N}_{2} \mathrm{O} \rightarrow 2 \mathrm{NO} \\
& \mathrm{O}\left({ }^{1} \mathrm{D}\right)+\mathrm{N}_{2} \mathrm{O} \rightarrow \mathrm{N}_{2}+\mathrm{O}_{2}
\end{aligned}
$$

The $\mathrm{O}_{3}$ produced from Reaction 17 could oxidize $\mathrm{NO}$ to $\mathrm{NO}_{2}$. Therefore, the photolysis of $\mathrm{N}_{2} \mathrm{O}$ eventually converts it to $\mathrm{NO}_{\mathrm{x}}$ which is concurrently measured by a commercial $\mathrm{NO}_{\mathrm{x}}$ detector (Thermo, Model 42i-TL) by converting $\mathrm{NO}_{2}$ to $\mathrm{NO}$ with a blue light converter and $\mathrm{NO}$ being measured by the chemiluminescence technique. The combined product $I t$ is a function of the mixing ratios of $\mathrm{N}_{2} \mathrm{O}, \mathrm{N}_{2}, \mathrm{O}_{2}$, and produced $\mathrm{NO}_{\mathrm{x}}$ :

$$
I t=\frac{\left(\mathrm{K}_{15} \times\left[\mathrm{O}_{2}\right]+\mathrm{K}_{16} \times\left[\mathrm{N}_{2}\right]+\left(\mathrm{K}_{18}+\mathrm{K}_{19}\right) \times\left[\mathrm{N}_{2} \mathrm{O}\right]\right) \times\left[\mathrm{NO}_{\mathrm{X}}\right]}{2 \times \mathrm{K}_{18} \times \sigma_{\mathrm{N}_{2} \mathrm{O}} \times \phi_{\mathrm{N}_{2} \mathrm{O}} \times\left[\mathrm{N}_{2} \mathrm{O}\right]^{2}}
$$


1 where $\mathrm{K}_{15}, \mathrm{~K}_{16}, \mathrm{~K}_{18}, \mathrm{~K}_{19}$ are the rate constants of Reaction 15, 16, 18 and 19, respectively,

2 whose values can be found elsewhere (Kurten et al., 2012). $\sigma_{\mathrm{N}_{2} \mathrm{O}}$ is the absorption cross-section

3 of $\mathrm{N}_{2} \mathrm{O}\left(1.43 \times 10^{-19} \mathrm{~cm}^{2}\right.$, Kurten et al., 2012) and $\phi_{\mathrm{N}_{2} \mathrm{O}}$ is the photolysis quantum yield which

4 is assumed to be 1.0 (Kurten et al., 2012).

5 Ideally, the $\mathrm{N}_{2} \mathrm{O}$ actinometry experiment should be conducted with the same flow rate as in

6 water vapor photolysis experiment such that the reaction time of these two photolysis

7 experiments can be the same. However, at the flow rate suitable for CIMS calibration (10 slpm),

8 the concentration of $\mathrm{NO}_{x}$ produced from $\mathrm{N}_{2} \mathrm{O}$ photolysis is close to the detection limit of the

$9 \quad \mathrm{NO}_{\mathrm{x}}$ detector. Hence, the $\mathrm{N}_{2} \mathrm{O}$ actinometry experiment was carried out at a lower flow rate (3 and 6 slpm) to increase reaction time for photolysis and then the $\mathrm{NO}_{\mathrm{x}}$ production. The It values for $\mathrm{N}_{2} \mathrm{O}$ photolysis experiment $\left(I t_{N_{2} \mathrm{O}}\right)$ and water vapor photolysis experiment $\left(I t_{\mathrm{H}_{2} \mathrm{O}}\right)$ have the following relationship:

$$
I t_{\mathrm{H}_{2} \mathrm{O}}=\frac{\mathrm{FR}_{\mathrm{N}_{2} \mathrm{O}} \times I t_{N_{2} \mathrm{O}}}{\mathrm{FR}_{\mathrm{H}_{2} \mathrm{O}}}
$$

where $\mathrm{FR}_{\mathrm{N}_{2} \mathrm{O}}$ and $\mathrm{FR}_{\mathrm{H}_{2} \mathrm{O}}$ represent the flow rate for the experiment of $\mathrm{N}_{2} \mathrm{O}$ photolysis and water vapor photolysis, respectively. Based on this equation, $I t_{\mathrm{H}_{2} \mathrm{O}}$ can be obtained by scaling $I t_{N_{2} O}$ with the ratio of $\mathrm{FR}_{\mathrm{N}_{2} \mathrm{O}}$ and $\mathrm{FR}_{\mathrm{H}_{2} \mathrm{O}}$. The relation in Equation 6 between the product $I t$ and flow rate is validated in the next section.

\subsubsection{It determination}

Figure 3 shows the results of $\mathrm{N}_{2} \mathrm{O}$ actinometry experiment. Figure $3 \mathrm{a}$ shows the $\mathrm{NO}_{\mathrm{x}}$ produced as the function of $\mathrm{N}_{2} \mathrm{O}$ mixing ratios from $10 \%$ to $15 \%$ at different flow rates $\left(\mathrm{FR}_{\mathrm{N}_{2} \mathrm{O}}=3,6\right.$, and $10 \mathrm{slpm}$ ). Generally, increasing $\mathrm{N}_{2} \mathrm{O}$ led to more production of $\mathrm{NO}_{\mathrm{x}}$, and the lower flow rate resulted in longer reaction time and the higher $\mathrm{NO}_{\mathrm{x}}$ concentrations. In figure $3 \mathrm{~b}$, the product It respect to different flow rate was calculated according to E5 based on the produced 
$1 \quad \mathrm{NO}_{\mathrm{x}}$ and $\mathrm{N}_{2} \mathrm{O}$ result in Figure 3a. The product $I t$ linearly increased with the inverse of the flow

2 rate, which validates the linear dependency between product It and inverse of the flow rate

3 shown by E6. This linear depend is consistent with a previous study (Kurten et al., 2012). In

4 addition, the product $I t$ was mostly independent on $\mathrm{N}_{2} \mathrm{O}$ mixing ratios with variation from $10 \%$

5 to $15 \%$. Figure $3 \mathrm{c}$ shows the flow rate scaled product $\mathrm{It}$ as a function of different $\mathrm{N}_{2} \mathrm{O}$ mixing

6 ratio. Based on the E6, the flow rate scaled product $I t\left(I t_{\mathrm{H}_{2} \mathrm{O}}\right)$ is calculated from $I t_{\mathrm{N}_{2} \mathrm{O}}$ in Figure

$73 \mathrm{~b}$ multiplying the ratio of $\mathrm{FR}_{\mathrm{N}_{2} \mathrm{O}}\left(3,6\right.$, and 10 slpm, respectively) to $\mathrm{FR}_{\mathrm{H}_{2} \mathrm{O}}(10 \mathrm{slpm})$. The

8 flow rate scaled product $I t$ variate from 1.37 to $1.53 \times 10^{11}$ at different flow rates and $\mathrm{N}_{2} \mathrm{O}$

9 mixing ratio. As a result, the value of $I t_{\mathrm{H}_{2} \mathrm{O}}$ was derived as $1.46 \times 10^{11}$ photon $\mathrm{cm}^{-1}$ from the average of flow rate scaled product $I t$.

\subsubsection{Calibration result}

Figure 4 shows an example of a typical procedure for determining the calibration factor. The instrument signals were continuously measured by adjusting $\mathrm{H}_{2} \mathrm{O}$ concentrations without changing other parameters. The different $\mathrm{OH}$ concentrations were calculated according to Equation 3. For each step, the signal intensities (in $\mathrm{Hz}$ ) of $\mathrm{HSO}_{4}^{-}$and $\mathrm{NO}_{3}^{-}$were collected for 6 minutes with background mode and signal mode of each 3 minutes. The calibration factors were determined from the calculated $\mathrm{OH}$ concentrations and signal intensities based on Equation 2. The red dots in Figure 4 represent the average calibration factors for every 3 minutes. The result shows that the calibration factors for different steps were very close from 1.60 to $1.69 \times 10^{-10}$ and were independent of water vapor concentrations, which indicates the high performance of calibration quantification. Then, the averaged calibration factor for our CIMS is $1.64 \times 10^{-10}$ molecule $/ \mathrm{cm}^{-3}$.

\section{Optimizations of instrument performance}


1 As shown in Figure 1, the CIMS system is complicated, and its performance is determined by

2 different parameters and components. In order to improve the performance of the CIMS for

$3 \mathrm{OH}$ measurement, different types of ion sources $\left({ }^{210} \mathrm{Po}\right.$ radioactive ion source, corona source),

4 scavenger gases (propane, $\mathrm{C}_{3} \mathrm{~F}_{6}$, and $\mathrm{NO}_{2}$ ), and primary ions detection were compared.

5 Moreover, the instrument sensitivity and noise were optimized by adjusting the flow rates and

6 voltages.

\section{$7 \quad$ 5.1. Ion source}

8 Radioactive ion source $\left({ }^{210} \mathrm{Po}\right.$ or $\left.{ }^{241} \mathrm{Am}\right)$ and corona discharge source (corona ionizer) were

9 generally used as the ion source in previous studies (Berresheim et al., 2000; Sjostedt et al.,

10 2007; Kukui et al., 2008). In this study, ${ }^{210}$ Po and corona sources were compared.

\section{$11 \quad \mathbf{5 . 1 . 1}^{210} \mathrm{Po}$}

12 The ${ }^{210} \mathrm{Po}$ acts as an ion source through the alpha decay. Briefly, ${ }^{210} \mathrm{Po}$ emitted alpha particles

13 that interact with the carrier gas to quickly form thermalized electrons and positive ions

14 (Fehsenfeld et al., 1975). The formed electrons react with $\mathrm{O}_{2}$ and then $\mathrm{HNO}_{3}$ to produce $\mathrm{NO}_{3}^{-}$.

$15\left(\mathrm{HNO}_{3}\right)_{\mathrm{m}} \cdot\left(\mathrm{H}_{2} \mathrm{O}\right)_{\mathrm{n}}$ reactant ions for ion conversion. Radioactive ion source such as ${ }^{210} \mathrm{Po}$ was

16 usually used due to the low $\mathrm{OH}$ interference and convenience of installation. We compared

$17{ }^{210} \mathrm{Po}$ ions source and corona source (see below) for the performance on $\mathrm{OH}$ measurements

18 (Figure S1). The result showed that the detection limit by ${ }^{210}$ Po ions source was lower than the

19 corona source. In this study, ${ }^{210} \mathrm{Po}$ foils were chosen as the ion source in our CIMS system. We

20 note that the radioactive ion source is usually subject to stringent health safety regulations and

21 the users should apply a permit to use the radioactive source. In addition, ${ }^{210} \mathrm{Po}$ is an isotope of

22 polonium and undergoes alpha decay to stable ${ }^{206} \mathrm{~Pb}$ with a half-life of about 140 days.

23 Therefore, in order to keep stable signal intensities for primary ions, ${ }^{210}$ Po foils need to be

24 replaced regularly. 


\subsubsection{Corona source}

2 Corona ionizer generates $\mathrm{NO}_{3}{ }^{-}$by the discharge formed between the tungsten needle and a 1

$3 \mathrm{~mm}$ diameter plate $3 \mathrm{~mm}$ from the needle tip (Kukui et al., 2008). Corona source has the

4 advantage of producing much higher concentrations of $\mathrm{NO}_{3}^{-} \cdot\left(\mathrm{HNO}_{3}\right)_{\mathrm{m}} \cdot\left(\mathrm{H}_{2} \mathrm{O}\right)_{\mathrm{n}}$ primary ions

5 compared with radioactive ${ }^{210} \mathrm{Po}$ or ${ }^{241} \mathrm{Am}$ foils, which leads to higher concentrations of $\mathrm{HSO}_{4}^{-}$

6 and higher signal intensities (higher sensitivities). However, the corona discharge source is

7 known to produce a significant amount of neutral species including $\mathrm{OH}$ radicals. When using

8 the corona discharge source in our CIMS instrument, the concentrations of produced $\mathrm{OH}$

9 artifacts were much higher than those found in the ambient atmosphere (Figure S1). Although

10 scavenger gas added in the sheath flow can remove most artificial $\mathrm{OH}$ radicals, the remaining

11 interferences are still comparable with those in ambient environments and can deteriorate the

12 detection limit of the CIMS instrument for $\mathrm{OH}$ measurements.

\section{$13 \quad 5.2$ Scavenger gas}

14 As discussed in Section 3, scavenger gas is very important for determining the performance of

$15 \mathrm{OH}$ measurement by CIMS. Three types of scavenger gas (propane, $\mathrm{C}_{3} \mathrm{~F}_{6}$, and $\mathrm{NO}_{2}$ ) have been used in previous studies by different groups (Berresheim et al., 2000; Sjostedt et al., 2007;

17 Kukui et al., 2008). However, there have been no reports on comparisons of these three

18 scavenger gases. In this study, they were tested in the laboratory. A scavenger gas was added in two positions for different purposes. In the sheath flow, the scavenger gas reduced the interference of $\mathrm{OH}$ artifacts from the ion source; in the sample flow, it was injected to eliminate

21 the ambient $\mathrm{OH}$ to determine background.

\subsubsection{Propane}

23 For propane, 99.95 vol.\% pure propane (purchase from the Harvest Wise Gases (H.K.)

24 Company) added in sheath flow could effectively ( $~ 80 \%$ see Figure 6$)$ remove artificial OH 
1 radicals from the ion source, and the remaining contributed a low and stable signal intensity at

$297 \mathrm{~m} / \mathrm{z}$. For the $\mathrm{OH}$ removal efficiency of propane in sample air, even at $\mathrm{OH}$ concentrations of

3 two orders of magnitude higher than ambient $\mathrm{OH}$ level, propane could remove $\mathrm{OH}$ at $97.7 \%$

4 (for more details, see Section 5.4.3). In addition, the signal intensity of the primary ions was

5 not affected by the added propane and kept stable (Figure S2). Propane is cheap and easy to

6 purchase. In our CIMS system, propane was selected as the scavenger gas.

\section{$7 \quad 5.2 .2 \mathrm{C}_{3} \mathrm{~F}_{6}$}

8 For $\mathrm{C}_{3} \mathrm{~F}_{6}$, although its $\mathrm{OH}$ removal efficiency was high enough, it was found to suppress the

9 signal intensities detected by the mass spectrometer system. With no $\mathrm{C}_{3} \mathrm{~F}_{6}$, the signal intensity

10 at $64 \mathrm{~m} / \mathrm{z}$ for primary ions was quite stable even within one month. However, once $\mathrm{C}_{3} \mathrm{~F}_{6}$ was

11 added, the signal intensity at $64 \mathrm{~m} / \mathrm{z}$ declined quickly as shown in Figure $\mathrm{S} 2$. As a result, the

12 sensitivity for $\mathrm{OH}$ measurements decreased and the detection limit increased. Initially, we

13 suspected that the purchased $\mathrm{C}_{3} \mathrm{~F}_{6}$ cylinder gas had high impurities, which may consume $\mathrm{NO}_{3}^{-}$

14 ions. But, after replacing three different $\mathrm{C}_{3} \mathrm{~F}_{6}$ cylinders gas which was purchased from two

15 different suppliers, the problem remained. We suspect that $\mathrm{C}_{3} \mathrm{~F}_{6}$ may suppress the ion detection efficiency of the mass spectrometer system.

\section{$17 \quad 5.2 .3 \mathrm{NO}_{2}$}

$\mathrm{NO}_{2}$ was found not only to remove $\mathrm{OH}$ radicals but also to $\mathrm{HO}_{2}$ radicals by converting them into $\mathrm{HO}_{2} \mathrm{NO}_{2}$ when $\mathrm{NO}$ was present in sample air. This means that compared to the other scavenger gases, $\mathrm{NO}_{2}$ provides a better measurement accuracy, especially in a high $\mathrm{NO}$ environment. However, only $1.0 \mathrm{vol} . \% \mathrm{NO}_{2}$ cylinder gas was available for our experiment due to restrictions of using higher concentrations of $\mathrm{NO}_{2}$, and its removal efficiency was not high enough to remove $\mathrm{OH}$. We note that high purity $\mathrm{NO}_{2}$ gas is very dangerous and must be handled with extreme caution. 


\subsection{Primary ions detection}

2 Determination of the concentrations of $\mathrm{OH}$ radicals need to use the signal intensities of $\mathrm{NO}_{3}^{-}$

3 ions according to Equation 2. In our study, $\mathrm{NO}_{3}^{-}$primary ions are detected by the mass

4 spectrometer system at $64 \mathrm{~m} / \mathrm{z}$. Some studies traced the $\mathrm{NO}_{3}^{-}$ions based on the signal intensities

5 at $62 \mathrm{~m} / \mathrm{z}$ (Tanner et al., 1997). However, we noticed that the concentrations of $\mathrm{NO}_{3}^{-}$produced

6 in the inlet system are extremely high. Even though a small portion of the $\mathrm{NO}_{3}^{-}$ions are finally

7 detected by the mass spectrometer system, they can yield very strong signal intensities. After

8 operating the CIMS instrument with detecting the signal of $\mathrm{NO}_{3}^{-}$ions at $62 \mathrm{~m} / \mathrm{z}$ about half a

9 year, we found a significant decrease in the signal intensity at $62 \mathrm{~m} / \mathrm{z}$ (with all instrument

10 settings unchanged), which may be due to the accelerated aging of the channeltron detector by

11 the high $\mathrm{NO}_{3}^{-}$ions concentrations. Therefore, the isotopic signal $\left(\mathrm{N}^{18} \mathrm{O}_{3}^{-}\right)$at $64 \mathrm{~m} / \mathrm{z}$ was chosen

12 to detect $\mathrm{NO}_{3}^{-}$primary ions for extended operation. The signal intensity at $64 \mathrm{~m} / \mathrm{z}$ is lower than

13 at $62 \mathrm{~m} / \mathrm{z}$ by about a factor of 167 (Kurten et al., 2012).

\subsection{Instrument sensitivity and noise}

\subsubsection{Parameters influencing the sensitivity}

The sensitivity (S) of the CIMS instrument to the $\mathrm{OH}$ radicals dependent on the reaction efficiency of $\mathrm{OH}$ and $\mathrm{SO}_{2}$ in chemical titration region ( $\mathrm{f}(\mathrm{RE})$ ), the conversion efficiency of $\mathrm{H}_{2} \mathrm{SO}_{4}$ to $\mathrm{HSO}_{4}^{-}$in chemical ionization region ( $\mathrm{f}(\mathrm{CE})$ ), and the transmitted efficiency of $\mathrm{HSO}_{4}^{-}$ from sample inlet to mass spectrometer system (f(TE)):

$$
S \sim f(R E) \cdot f(C E) \cdot f(T E)
$$

$\mathrm{f}(\mathrm{RE})$ is dependent on the reaction time and the reaction rate, which is mainly related to the velocity of sample air flow and the concentration of $\mathrm{SO}_{2} . \mathrm{f}(\mathrm{CE})$ is mainly controlled by the mixing of $\mathrm{H}_{2} \mathrm{SO}_{4}$ in sample flow and $\mathrm{NO}_{3}^{-} \cdot\left(\mathrm{HNO}_{3}\right)_{\mathrm{m}} \cdot\left(\mathrm{HO}_{2}\right)_{\mathrm{n}}$ primary ions in sheath flow in 
1 the chemical ionization region, which is not only dependent on the mixing of sample flow and

2 sheath flow but also the voltages on the flow tubes as discussed in Section 3.1. $\mathrm{f}(\mathrm{RE})$ is related

3 to the $\mathrm{N}_{2}$ buffer gas flow and voltages. We can optimize the sensitivity (S) by adjusting the

$4 \quad \mathrm{SO}_{2}$ flow, sample/sheath flows, $\mathrm{N}_{2}$ buffer gas flow, and voltages.

\section{$5 \quad$ 5.4.2 Sensitivity optimization}

\section{$6 \quad$ 5.4.2.1 Optimization of $\mathrm{SO}_{2}$ gas flow}

7 Figure 5a shows the normalized signal intensity (NSI) at $97 \mathrm{~m} / \mathrm{z}$ for $\mathrm{HSO}_{4}^{-}$as a function of the

8 flow rate of $\mathrm{SO}_{2}(0.9 \mathrm{vol} . \%)$. The NSI first increased with increased $\mathrm{SO}_{2}$. Then, the NSI became

9 independent of the added $\mathrm{SO}_{2}$ amount and a stable signal was obtained with flow rate $>\sim 2.5$

$10 \mathrm{sccm}$. We set the $\mathrm{SO}_{2}$ flow rate $5 \mathrm{sccm}$ for a factor of 2 margin $\mathrm{sccm}$ for our operation,

11 following the previous study (Sjostedt et al., 2007).

\section{$12 \quad$ 5.4.2.2 Optimization of sample/sheath flow}

13 Figure $5 \mathrm{~b}$ shows the NSI as a function of the ratio of sample flow to sheath flow. The NSI

14 firstly increased and then decreased with the increased ratio, with a peak value at a 15 sample/sheath flow ratio of 0.3 . This ratio was independent of the sample flow rates from 12 to 21 slpm. We think that this ratio produced a turbulent total flow in the chemical ionization region, facilitating a fast mixing of the reactants, enhancing the ionization efficiency of $\mathrm{H}_{2} \mathrm{SO}_{4}$, and increasing NSI at $97 \mathrm{~m} / \mathrm{z}$. (Tanner and Eisele, 1995; Tanner et al., 1997).

The effects of the sample flow rate on NSI are shown in Figure 5c. The ratio of sample to sheath flow was fixed as 0.3 . Briefly, the NSI increased with the decreased flow rate. The result

21 is expected as the lower the sample flow rate is, the longer times Reactions 1-3, as well as Reaction 6, have, which improves both $\mathrm{f}(\mathrm{RE})$ and $\mathrm{f}(\mathrm{CE})$. However, the increased reaction time of Reactions 1-3 will increase the $\mathrm{OH}$ interference produced from the $\mathrm{HO}_{2}$ recycling in the presence of NO in sample air. Previous studies usually kept the reaction time less than $60 \mathrm{~ms}$ 
1 (e.g. Tanner et al., 1997). After considering these two factors, the sample and sheath flow rates

2 were set at 3.7 and 12.6 slpm, respectively, which gives a reaction time of $\sim 47 \mathrm{~ms}$. The optimal

$3 \mathrm{f}(\mathrm{RE})$ is determined.

\section{$4 \quad$ 5.4.2.3 Optimization of voltages}

5 Figure 5d-e shows the effects of voltages on NSI. As mentioned above, the voltages are applied to force the ions to the centre of the chemical ionization region and enhances the ionization

7 efficiency. Similar to the flow ratio, the increase of voltage difference (inlet voltage minus

8 sheath voltage) firstly increased the NSI and then decreased it (Figure 5d). At the voltage

9 difference of $48 \mathrm{~V}$, the peak NSI was achieved. In Figure 5e, the NSI increased with the

10 negative sheath voltage and then kept stable with sheath voltage $<-70 \mathrm{~V}$ (the voltage difference

11 was fixed as $48 \mathrm{~V}$ ). based on these results, we set the inlet and sheath voltages at -32 and -80

$12 \mathrm{~V}$, respectively. At these settings, the optimal $\mathrm{f}(\mathrm{CE})$ was determined. The cross interactions of

13 sample/sheath flow and voltages on NSI were also evaluated in Figure S3. The highest NSI

14 was achieved when the sample/sheath flow ratio was close to 0.3 for different voltages. This

15 result indicates the response of NSI on voltages is relatively stable at the flow ratio of 0.3 . The

16 voltages added to the pinhole also force the ion to the central of pinhole and pass through it

17 which are set at -70 and $-40 \mathrm{~V}$.

\section{$18 \quad$ 5.4.2.4 Optimization of $\mathrm{N}_{2}$ buffer gas flow}

19 Generally, the mass flow into the mass spectrometer system is fixed and the $\mathrm{N}_{2}$ buffer gas just changes the amount of sample air versus dry $\mathrm{N}_{2}$. Figure $5 f$ shows the effect of $\mathrm{N}_{2}$ buffer gas

21 flow. Generally, the NSI increased with the decreased flow rate since more ions in sample air entered the mass spectrometer system and further increased the $\mathrm{f}(\mathrm{TE})$. However, a lower flow rate of $\mathrm{N}_{2}$ buffer gas also makes more neutral molecules in sample air entering the mass 
1 spectrometer system and influencing the instrument (Berresheim et al., 2000). Therefore, the

2 flow rate of $\mathrm{N}_{2}$ buffer gas was set as $440 \mathrm{sccm}$, and the optimal $\mathrm{f}(\mathrm{TE})$ was determined.

\section{$3 \quad 5.4 .3$ Noise minimization}

4 As discussed above, the instrument noises for $\mathrm{OH}$ measurements are from $\mathrm{H}_{2} \mathrm{SO}_{4}$ in ambient

5 air and $\mathrm{OH}$ produced by the ion source. These noises can be reduced by adding a scavenger 6 gas.

7 In order to minimize the artificial $\mathrm{OH}$ produced by ion source, the scavenger gas was added to

8 sheath flow. Figure 6 shows the signal intensity at $97 \mathrm{~m} / \mathrm{z}$ where $\mathrm{N}_{2}$ gas was used as sample air

9 so that there were no $\mathrm{OH}$ radicals in sample air. The artificial $\mathrm{OH}$ signal from the ${ }^{210} \mathrm{Po}$ ion

10 source was $\sim 3.5 \times 10^{6}$ molecules $\mathrm{cm}^{-3}$ without propane in sheath gas, which is comparable to

11 the typical $\mathrm{OH}$ concentrations in ambient environments. When propane was added into the

12 sheath gas, the artificial signals were effectively reduced to less than $\sim 1 \times 10^{6}$ molecules $\mathrm{cm}^{-3}$

13 and kept stable when the flow rate was higher than $1 \mathrm{sccm}$. Based on the result, we set a flow rate of $2 \mathrm{sccm}$ for propane in the sheath flow.

15 To quantify and subsequently remove the contribution of ambient $\mathrm{H}_{2} \mathrm{SO}_{4}$ to signal at $97 \mathrm{~m} / \mathrm{z}$,

\section{Detection limit and uncertainty}


1 The detection limit can be calculated as follows,

$2 \quad D L=\frac{1}{C} \times \frac{n * \sigma}{\left\{\mathrm{NO}_{3}^{-}\right\}}$

3 Where DL is the detection limit in $10^{6}$ molecule $/ \mathrm{cm}^{3}, \mathrm{C}$ is the calibration factor, and $n$ is the

4 ratio of signal to noise $\mathrm{S} / \mathrm{N}$. $\sigma$ represents the standard deviation of the signal intensity of $\mathrm{HSO}_{4}^{-}$

5 at $97 \mathrm{~m} / \mathrm{z}$, and $\left\{\mathrm{NO}_{3}^{-}\right\}$represents the signal intensity of $\mathrm{NO}_{3}^{-}$at $64 \mathrm{~m} / \mathrm{z}$ at the integration time t.

6 Figure 8 shows the concentrations of $\mathrm{OH}$ radicals and the corresponding detection limit $(\mathrm{S} / \mathrm{N}=2$,

7 average time $=6$ minutes $)$ in the laboratory. The detection limit was quite stable over the whole

8 day and ranged from 0.08 to $0.20 * 10^{6}$ molecule $\mathrm{cm}^{-3}$, with an average value of approximately

$9 \quad 0.15 * 10^{6}$ molecule $\mathrm{cm}^{-3}$.

10 The uncertainty for the calibration factor (C) of $\mathrm{OH}$ measurements is dependent on the

11 uncertainties of all the parameters involved in the calculation of the concentrations of $\mathrm{OH}$

12 radicals and the precision of the measurements of signal at $64 \mathrm{~m} / \mathrm{z}$ and $97 \mathrm{~m} / \mathrm{z}$. The uncertainty

13 was $\sim 36 \%$ for $I t$ (see Figure 3), $\sigma_{\mathrm{H}_{2} \mathrm{O}} \sim 5 \%$ for $\sigma_{\mathrm{H}_{2} \mathrm{O}},<1 \%$ for $\phi_{\mathrm{H}_{2} \mathrm{O}}$ (Cantrell et al. 1997), and

$14 \sim 10 \%$ for the water concentration (Kukui et al., 2008). The precision of the measurements

15 signal at $64 \mathrm{~m} / \mathrm{z}$ and $97 \mathrm{~m} / \mathrm{z}$ of the CIMS instrument $(2 \sigma)$ was $11 \%$ (for 6 min integration time).

16 The overall uncertainty for the calibration factor was about $38 \%$.

\section{Field deployment of CIMS}

18 In order to examine the performance of our CIMS in the ambient environment, we deployed

19 the optimized instrument to an urban site of Hong Kong in April 2019 (Figure S4). The site

20 was located on the $11^{\text {th }}$ floor of a teaching building on the campus of The Hong Kong

21 Polytechnic University (PolyU) and was surrounded by several busy roads. The sample inlet

22 was positioned horizontally facing the south. Measurements were made with a time resolution

23 of 10 seconds. A typical measurement sequence consisted of 3 minutes in the background mode 
and 3 minutes in the signal mode. Figure 9a shows the diurnal profile of $\mathrm{OH}$ concentrations (3minute average) observed on April 25, 2019, and the solar radiation measured using UTALI200 at a time resolution of 1 minute. Figure $9 \mathrm{~b}$ shows the measured signal intensities at 97 $\mathrm{m} / \mathrm{z}$ at the signal mode and the background mode. The $\mathrm{OH}$ concentrations exhibited a clear diurnal profile with the highest value of $\sim 6 \times 10^{6}$ molecules $\mathrm{cm}^{-3}$ at midday and the lowest level of $\sim 0.25 \times 10^{6}$ molecules $\mathrm{cm}^{-3}$ at night. The $\mathrm{OH}$ concentrations were highly correlated to solar radiation, which was similar to previous studies (e.g. Rohrer and Berresheim, 2006; Tan et al.,

8 2017). The 3 -minute average $\mathrm{OH}$ concentrations were above the detection limits $\left(0.5-2 \times 10^{6}\right.$

9 molecules $\mathrm{cm}^{-3}$ ) most of the daytime, except during a cloudy period (08:00 to 10:00) (Figure 9a). This preliminary result demonstrated the capability of our CIMS for measuring ambient $\mathrm{OH}$ on a clear day in an urban environment. However, Figure $9 \mathrm{~b}$ reveals that the contribution to instrument background from ambient $\mathrm{H}_{2} \mathrm{SO}_{4}$ was significant at the site, which raised the detection limit and measurement uncertainty (to 51\%). Future work will make use of isotopically labelled ${ }^{34} \mathrm{SO}_{2}$ to eliminate $\mathrm{H}_{2} \mathrm{SO}_{4}$ interference.

\section{Summary and conclusions}

To measure the atmospheric $\mathrm{OH}$ radicals, we have developed the first chemical ionization mass spectrometry (CIMS) system in Asia. It is an indirect measurement technique that converts $\mathrm{OH}$ radicals to $\mathrm{HSO}_{4}^{-}$which is detected by the ion-assisted mass spectrometry method. In addition, the calibration system has been developed. A series of comparisons of different ion sources, scavenger gases, and primary ions detection have been conducted to optimize the performance of the CIMS for $\mathrm{OH}$ measurement. The sensitivity is dependent on the efficiencies of titration reaction, ion conversion, and ion transmission which have been improved by optimizing the flow rates of a myriad of gases and voltages in various components. An initial field test has demonstrated the capacity of this instrument in measuring ambient $\mathrm{OH}$ in an urban site on clear days. The main findings on the key parameters are summarized below. 
(1) ${ }^{210} \mathrm{Po}$ has lower artificial $\mathrm{OH}$ interference compared to a corona ionizer, and it is adopted as the ion source.

1

(2) $\mathrm{C}_{3} \mathrm{H}_{8}$ is a better $\mathrm{OH}$ scavenger than $\mathrm{C}_{3} \mathrm{~F}_{6}$ and $\mathrm{NO}_{2}$ (low concentration) because of the high elimination efficiency and signal stability of $\mathrm{C}_{3} \mathrm{H}_{8}$.

(3) A procedure has been developed to optimize the flow rates of sample gas, sheath gas, and $\mathrm{N}_{2}$ buffer gas, voltages on the sample inlet system and the concentration of $\mathrm{SO}_{2}$ titration gas with the aim to increase instrument's sensitivity and reduce noise.

(4) The CIMS instrument achieved a detection limit of $0.15 \times 10^{6}$ molecules $\mathrm{cm}^{-3}$ and uncertainty of $38 \%(\mathrm{~S} / \mathrm{N}=2)$ under laboratory conditions. In the field, the detection limit increased to about $0.15 \times 10^{6}$ molecules $\mathrm{cm}^{-3}$ on clear days, with the overall accuracy of about $51 \%$.

(5) Future work includes more field experiments in various environments and utilization of isotopically labelled ${ }^{34} \mathrm{SO}_{2}$ to eliminate the $\mathrm{H}_{2} \mathrm{SO}_{4}$ interference.

We note that the optimal values of instrument parameters may differ in different CIMS systems due to the different design and/or configurations, the test procedures and results from our study provide a useful reference to other researchers who wish to apply CIMS technique to measure atmospheric $\mathrm{OH}$ radicals.

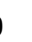


1 Data availability. All data used to produce this study can be obtained by contacting Tao Wang

3 Supplement. The supplement related to this article is available on line at:

4 Author contribution. TW invited the project, WP and ZZ designed and performed 5 experiments with contributions from WW, ZW, DT and TW. WP, ZZ, and TW write the paper

6 with contributions from DT and ZW.

7 Competing interests. The authors declare that they have no conflict of interest.

\section{Acknowledgments}

9 We thank the Environmental Protection Department of Hong Kong for loaning the CIMS instrument.

Financial support. This research was financially supported by the Hong Kong Research

\section{Reference:}

Berresheim, H., Elste, T., Plass-Dülmer, C., Eisele, F. L. and Tanner, D. J.: Chemical ionization mass spectrometer for long-term measurements of atmospheric $\mathrm{OH}$ and $\mathrm{H} 2 \mathrm{SO} 4$, Int. J. Mass Spectrom., 202(1-3), 91-109, doi:10.1016/S1387-3806(00)00233-5, 2000.

Berresheim, H., McGrath, J., Adam, M., Mauldin, R. L., Bohn, B., \& Rohrer, F. (2013). Seasonal measurements of $\mathrm{OH}, \mathrm{NOx}$, and J(O1D) at Mace Head, Ireland. Geophysical Research Letters, 40(8), 1659-1663. https://doi.org/10.1002/grl.50345

Calvert, J. G., Lazrus, A., Kok, G. L., Heikes, B. G., Walega, J. G., Lind, J. and Cantrell, C. A.: Chemical mechanisms of acid generation in the troposphere, Nature, 317(6032), 27-35, doi:10.1038/317027a0, 1985.

Cantrell, C. A., Zimmer, A. and Tyndall, G. S.: Absorption cross sections for water vapor from 183 to 193 nm, Geophys. Res. Lett., 24(17), 2195-2198, doi:10.1029/97GL02100, 1997.

Crosley, D. R.: 1993 Tropospheric OH Photochemistry Experiment: A summary and perspective, J. Geophys. Res. Atmos., 102(5), 6495-6510, doi:10.1029/96jd03324, 1997.

Edwards, G. D., Cantrell, C. A., Stephens, S., Hill, B., Goyea, O., Shetter, R. E., Mauldin, R. L., Kosciuch, E., Tanner, D. J., \& Eisele, F. L. (2003). Chemical Ionization Mass Spectrometer Instrument for the Measurement of Tropospheric HO2 and RO2. Analytical Chemistry, 75(20), 5317-5327. https://doi.org/10.1021/ac034402b

Eisele, F. L. and Tanner, D. J.: Ion-assisted tropospheric $\mathrm{OH}$ measurements, edited by Intergovernmental Panel on Climate Change, J. Geophys. Res., 96(D5), 9295-9308, doi:10.1029/91JD00198, 1991. 
4 Fehsenfeld, F. C., Howard, C. J. and Schmeltekopf, A. L.: Gas phase ion chemistry of HNO3, J. Chem. 5 Phys., 63(7), 2835-2841, doi:10.1063/1.431722, 1975.

6 Feiner, P. A., Brune, W. H., Miller, D. O., Zhang, L., Cohen, R. C., Romer, P. S., Goldstein, A. H., Keutsch, 7 F. N., Skog, K. M., Wennberg, P. O., Nguyen, T. B., Teng, A. P., DeGouw, J., Koss, A., Wild, R. J., Brown, 8 S. S., Guenther, A., Edgerton, E., Baumann, K. and Fry, J. L.: Testing atmospheric oxidation in an 9 Alabama forest, J. Atmos. Sci., 73(12), 4699-4710, doi:10.1175/JAS-D-16-0044.1, 2016.

Fuchs, H., Dorn, H. P., Bachner, M., Bohn, B., Brauers, T., Gomm, S., Hofzumahaus, A., Holland, F., Nehr, S., Rohrer, F., Tillmann, R. and Wahner, A.: Comparison of $\mathrm{OH}$ concentration measurements by DOAS and LIF during SAPHIR chamber experiments at high $\mathrm{OH}$ reactivity and low NO concentration, Atmos. Meas. Tech., 5(7), 1611-1626, doi:10.5194/amt-5-1611-2012, 2012. 5163-5198, doi:10.1021/cr020522s, 2003.

Hofzumahaus, A., Rohrer, F., Lu, K., Bohn, B., Brauers, T., Chang, C.-C., Fuchs, H., Holland, F., Kita, K., Kondo, Y., Li, X., Lou, S., Shao, M., Zeng, L., Wahner, A. and Zhang, Y.: Amplified Trace Gas Removal in the Troposphere, Science (80-. )., 324(5935), 1702-1704, doi:10.1126/science.1164566, 2009.

Holland, F., Hessling, M. and Hofzumahaus, A.: In situ measurement of tropospheric $\mathrm{OH}$ radicals by laser-induced fluorescence - a description of the KFA instrument, J. Atmos. Sci., 52(19), 3393-3401, doi:10.1175/1520-0469(1995)052<3393:ISMOTO>2.0.CO;2, 1995.

Kukui, A., Ancellet, G. and Le Bras, G.: Chemical ionisation mass spectrometer for measurements of $\mathrm{OH}$ and Peroxy radical concentrations in moderately polluted atmospheres, J. Atmos. Chem., 61(2), 133-154, doi:10.1007/s10874-009-9130-9, 2008.

Kulmala, M., Vehkamäki, H., Petäjä, T., Dal Maso, M., Lauri, A., Kerminen, V. M., Birmili, W. and McMurry, P. H.: Formation and growth rates of ultrafine atmospheric particles: $A$ review of observations, J. Aerosol Sci., 35(2), 143-176, doi:10.1016/j.jaerosci.2003.10.003, 2004.

Kürten, A., Rondo, L., Ehrhart, S. and Curtius, J.: Calibration of a chemical ionization mass spectrometer for the measurement of gaseous sulfuric acid, J. Phys. Chem. A, 116(24), 6375-6386, doi:10.1021/jp212123n, 2012.

Lelieveld, J., Butler, T. M., Crowley, J. N., Dillon, T. J., Fischer, H., Ganzeveld, L., Harder, H., Lawrence, M. G., Martinez, M., Taraborrelli, D. and Williams, J.: Atmospheric oxidation capacity sustained by a tropical forest, Nature, 452(7188), 737-740, doi:10.1038/nature06870, 2008.

Levy, H.: Normal atmosphere: Large radical and formaldehyde concentrations predicted, Science (80-. )., 173(3992), 141-143, doi:10.1126/science.173.3992.141, 1971. B., Artaxo, P., Souza, R. A. F., McKinney, K. A. and Martin, S. T.: Isoprene photo-oxidation products quantify the effect of pollution on hydroxyl radicals over Amazonia, Sci. Adv., 4(4), 1-9, doi:10.1126/sciadv.aar2547, 2018. A.: Observation and modelling of $\mathrm{OH}$ and $\mathrm{HO} 2$ concentrations in the Pearl River Delta 2006: A missing $\mathrm{OH}$ source in a VOC rich atmosphere, Atmos. Chem. Phys., 12(3), 1541-1569, doi:10.5194/acp-121541-2012, 2012. 

atmospheric free-radical chemistry in China: The self-cleansing capacity and the formation of 3 secondary air pollution, Natl. Sci. Rev., 6(3), 579-594, doi:10.1093/nsr/nwy073, 2019.

4 Mao, J., Ren, X., Zhang, L., Van Duin, D. M., Cohen, R. C., Park, J. H., Goldstein, A. H., Paulot, F., Beaver, 5 M. R., Crounse, J. D., Wennberg, P. O., Digangi, J. P., Henry, S. B., Keutsch, F. N., Park, C., Schade, G. 6 W., Wolfe, G. M., Thornton, J. A. and Brune, W. H.: Insights into hydroxyl measurements and 7 atmospheric oxidation in a California forest, Atmos. Chem. Phys., 12(17), 8009-8020, 8 doi:10.5194/acp-12-8009-2012, 2012.

9 Mauldin, R. L., Frost, G. J., Chen, G., Tanner, D. J., Prevot, A. S. H., Davis, D. D. and Eisele, F. L.: $\mathrm{OH}$ measurements during the First Aerosol Characterization Experiment (ACE 1): Observations and model comparisons, J. Geophys. Res. Atmos., 103(D13), 16713-16729, doi:10.1029/98JD00882, 1998.

McKeen, S. A., Mount, G., Eisele, F., Williams, E., Harder, J., Goldan, P., Kuster, W., Liu, S. C., Baumann, K., Tanner, D., Fried, A., Sewell, S., Cantrell, C. and Shetter, R.: Photochemical modeling of hydroxyl and its relationship to other species during the Tropospheric $\mathrm{OH}$ Photochemistry Experiment, J. Geophys. Res. Atmos., 102(5), 6467-6493, doi:10.1029/96jd03322, 1997.

Novelli, A., Vereecken, L., Lelieveld, J. and Harder, H.: Direct observation of $\mathrm{OH}$ formation from stabilised Criegee intermediates, Phys. Chem. Chem. Phys., 16(37), 19941-19951, doi:10.1039/c4cp02719a, 2014.

Peeters, J., Nguyen, T. L. and Vereecken, L.: HOx radical regeneration in the oxidation of isoprene, Phys. Chem. Chem. Phys., 11(28), 5935-5939, doi:10.1039/b908511d, 2009.

Perner, D., Ehhalt, D. H., Pätz, H. W., Platt, U., Röth, E. P. and Volz, A.: OH - Radicals in the lower troposphere, Geophys. Res. Lett., 3(8), 466-468, doi:10.1029/GL003i008p00466, 1976.

Rohrer, F. and Berresheim, H.: Strong correlation between levels of tropospheric hydroxyl radicals and solar ultraviolet radiation, Nature, 442(7099), 184-187, doi:10.1038/nature04924, 2006.

Sjostedt, S. J., Huey, L. G., Tanner, D. J., Peischl, J., Chen, G., Dibb, J. E., Lefer, B., Hutterli, M. A., Beyersdorf, A. J., Blake, N. J., Blake, D. R., Sueper, D., Ryerson, T., Burkhart, J. and Stohl, A.: Observations of hydroxyl and the sum of peroxy radicals at Summit, Greenland during summer 2003, Atmos. Environ., 41(24), 5122-5137, doi:10.1016/j.atmosenv.2006.06.065, 2007.

Stone, D., Whalley, L. K. and Heard, D. E.: Tropospheric $\mathrm{OH}$ and $\mathrm{HO} 2$ radicals: Field measurements and model comparisons, Chem. Soc. Rev., 41(19), 6348-6404, doi:10.1039/c2cs35140d, 2012.

Tan, Z., Fuchs, H., Lu, K., Hofzumahaus, A., Bohn, B., Broch, S., Dong, H., Gomm, S., Häseler, R., He, L., Holland, F., Li, X., Liu, Y., Lu, S., Rohrer, F., Shao, M., Wang, B., Wang, M., Wu, Y., Zeng, L., Zhang, Y., Wahner, A. and Zhang, Y.: Radical chemistry at a rural site (Wangdu) in the North China Plain: Observation and model calculations of $\mathrm{OH}, \mathrm{HO} 2$ and RO2 radicals, Atmos. Chem. Phys., 17(1), 663690, doi:10.5194/acp-17-663-2017, 2017.

Tanner, D. J. and Eisele, F. L.: Present $\mathrm{OH}$ measurement limits and associated uncertainties, J. Geophys. Res., 100(D2), 2883-2892, doi:10.1029/94JD02609, 1995.

Tanner, D. J., Jefferson, A. and Eisele, F. L.: Selected ion chemical ionization mass spectrometric measurement of OH, J. Geophys. Res. Atmos., 102(5), 6415-6425, doi:10.1029/96jd03919, 1997.

40 Wang, T., Xue, L., Brimblecombe, P., Lam, Y. F., Li, L. and Zhang, L.: Ozone pollution in China: A review 41 of concentrations, meteorological influences, chemical precursors, and effects, Sci. Total Environ., 575, 42 1582-1596, doi:10.1016/j.scitotenv.2016.10.081, 2017. 
https://doi.org/10.5194/amt-2020-252

Preprint. Discussion started: 13 July 2020

(c) Author(s) 2020. CC BY 4.0 License.

\section{Atmospheric

1 Wennberg, P. O., Stimpfle, R. M., Weinstock, E. M., Dessler, A. E., Lloyd, S. A., Lapson, L. B., Schwab, J. 2 J. and Anderson, J. G.: Simultaneous, in situ measurements of $\mathrm{OH}, \mathrm{HO} 2, \mathrm{O} 3$, and $\mathrm{H} 2 \mathrm{O}$ : A test of 3 modeled stratospheric HOx chemistry, Geophys. Res. Lett., 17(11), 1909-1912, 4 doi:10.1029/GL017i011p01909, 1990.

5 Whalley, L. K., Edwards, P. M., Furneaux, K. L., Goddard, A., Ingham, T., Evans, M. J., Stone, D., Hopkins, 6 J. R., Jones, C. E., Karunaharan, A., Lee, J. D., Lewis, A. C., Monks, P. S., Moller, S. J. and Heard, D. E.: 7 Quantifying the magnitude of a missing hydroxyl radical source in a tropical rainforest, Atmos. Chem. 8 Phys., 11(14), 7223-7233, doi:10.5194/acp-11-7223-2011, 2011. 


\section{Figures}

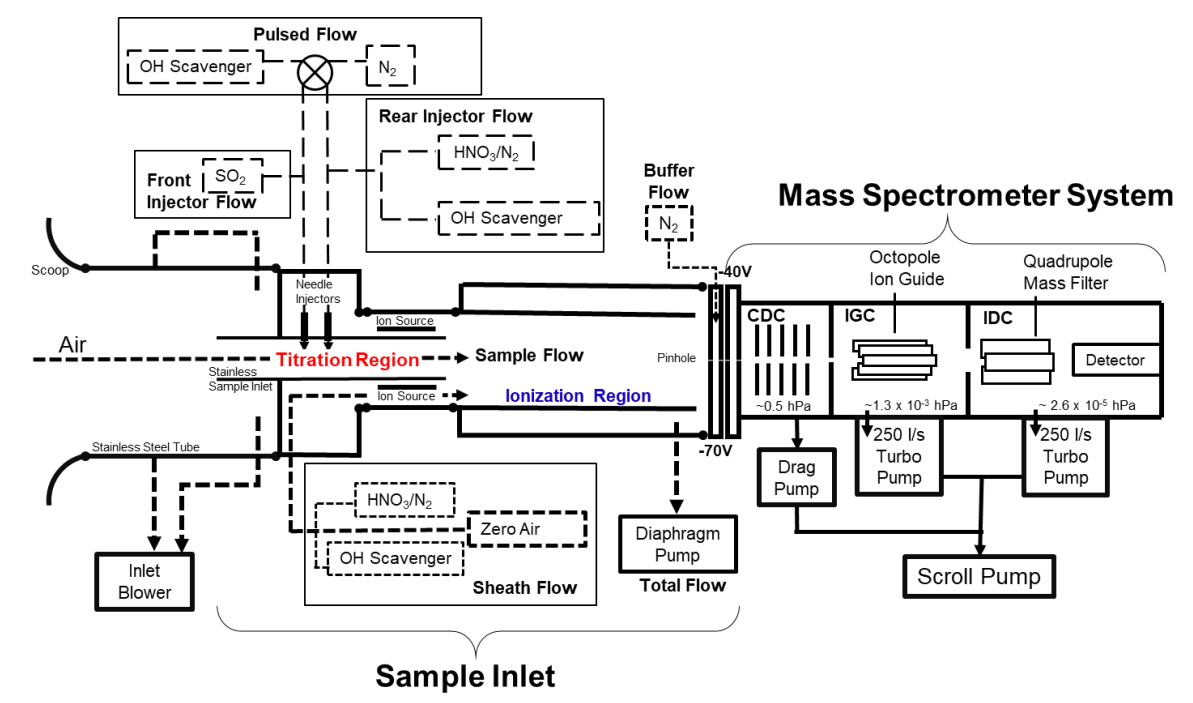

3 Figure 1. Schematic diagram of the OH-CIMS system, which including a sample inlet system and a 4 mass spectrometer system. The sample inlet system including chemical titration region and chemical 5 ionization region. The mass spectrometer system consists by a collisional dissociation chamber 6 (CDC), an ion guide chamber (IGC), and an ion detection chamber (IDC). Dashed lines depict the air 7 flows in the sample inlet during operations.

a)

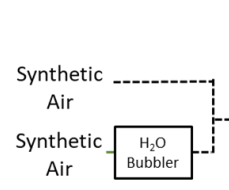

b)

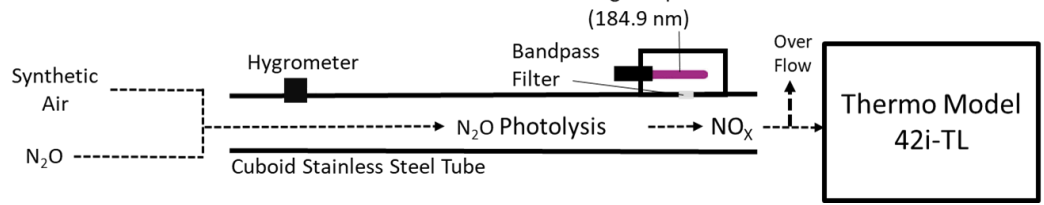

8

9

10

11

Figure 2. Schematic diagram of calibration. a) The CIMS calibration experiment. b) The $\mathrm{N}_{2} \mathrm{O}$ actinometry experiment for determination of product $I t$ value. Dashed lines show the air flows during experiment. 

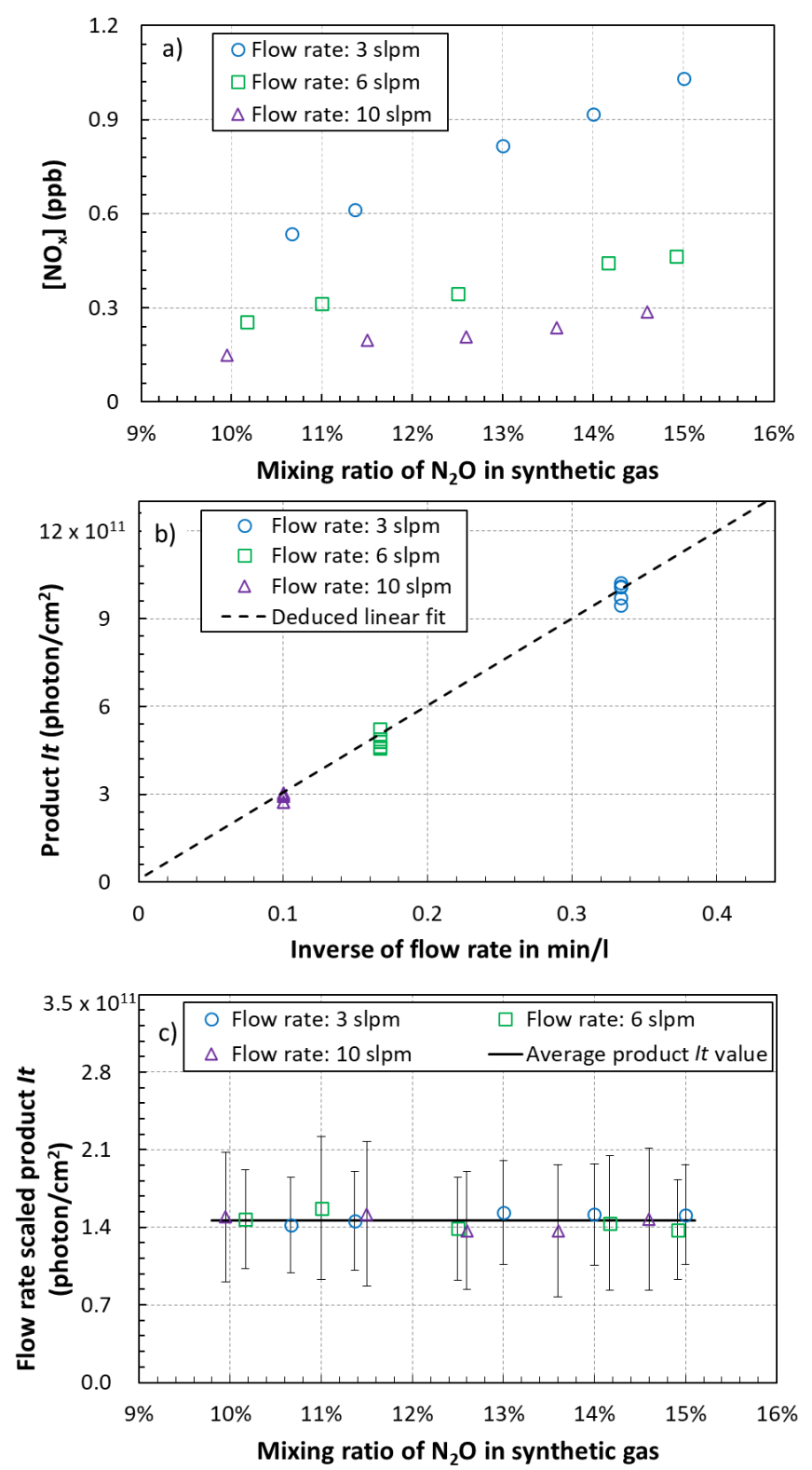

2 Figure 3. The results of $\mathrm{N}_{2} \mathrm{O}$ actinometry experiment. a) The produced $\mathrm{NO}_{\mathrm{x}}$ concentration as a 3 function of $\mathrm{N}_{2} \mathrm{O}$ mixing ratio. Different colors represent different flow rates. b) The product $I t$ as a 4 function of inverse of flow rate (see detail in text). c) The flow rate scaled product $I t$ as a function of $5 \quad \mathrm{~N}_{2} \mathrm{O}$ mixing ratio, which was obtained by scaling product $I t$ with the ratio of flow rates $(3,6$, and 10 $6 \mathrm{slpm}$ ) to $10 \mathrm{slpm}$. Black line is the average value of flow rate scaled product $I t$. The error bars 7 represent uncertainties $(2 \sigma)$ for flow rate scaled product $I t$. The average uncertainty of the product $I t$ is $836 \%$. 


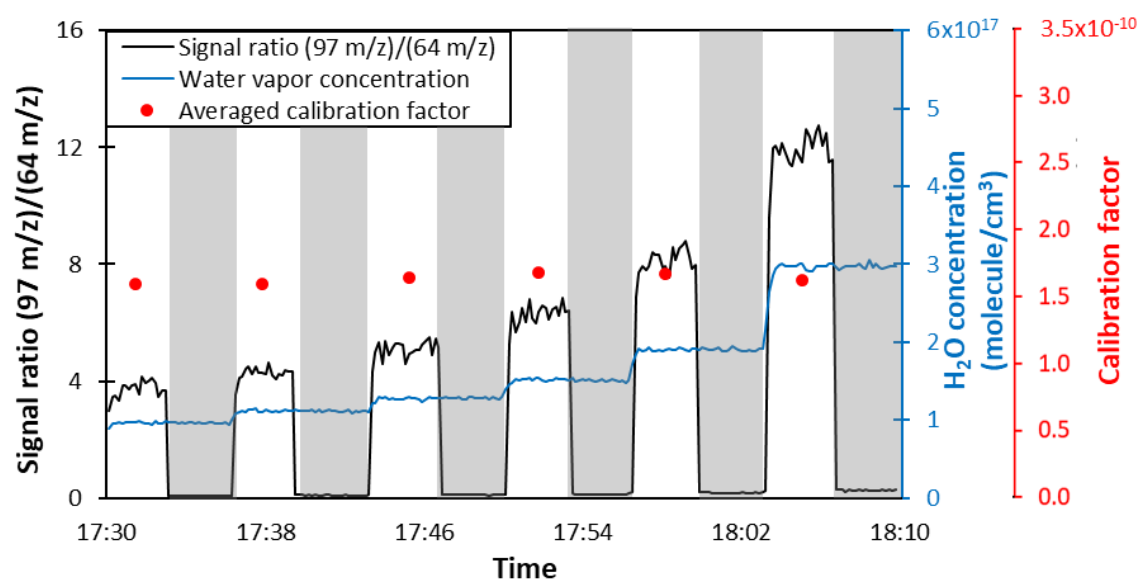

Figure 4. The time series showing calibration result. Gray labeled areas represent the background mode during calibration. Black line represents the ratio of signal intensity at $97 \mathrm{~m} / \mathrm{z}$ and $64 \mathrm{~m} / \mathrm{z}$. Blue line represents water vapor concentration. Red dots represent the 3-minute averaged calibration factors at different steps.
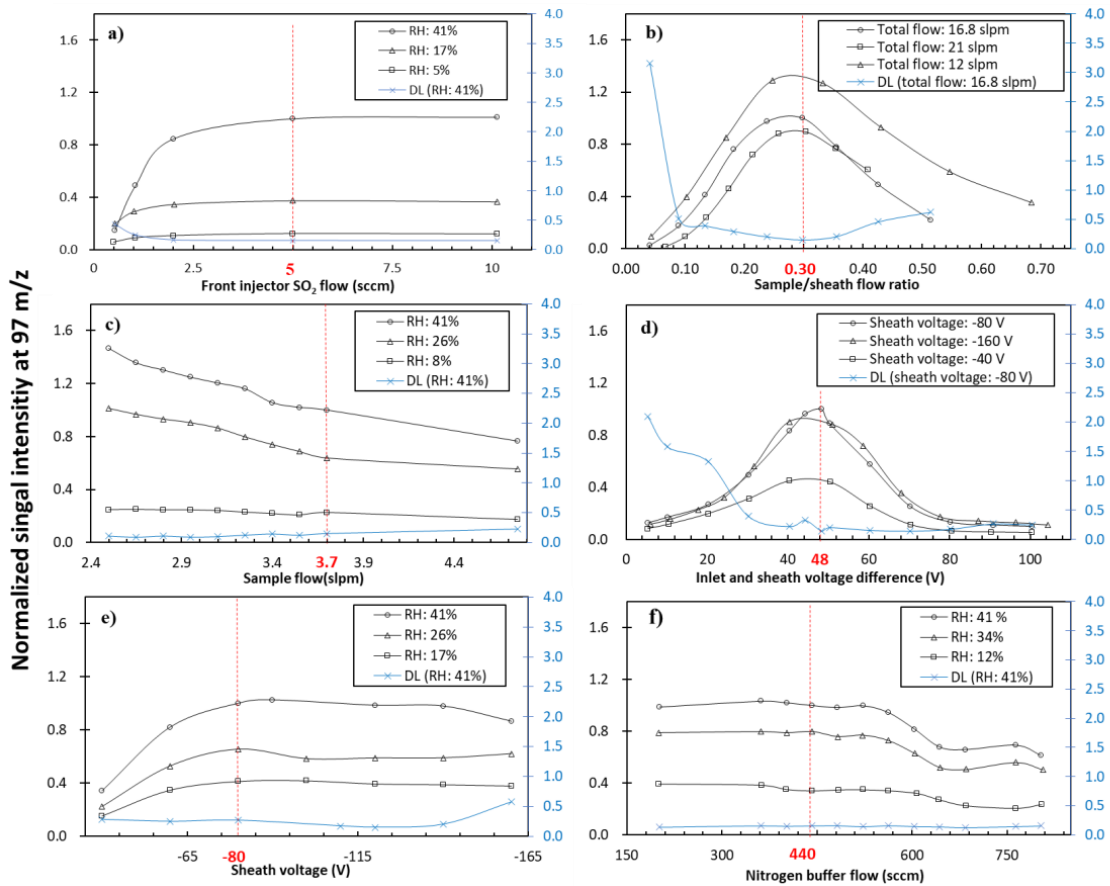
1 Figure 5. The normalized signal intensity at $97 \mathrm{~m} / \mathrm{z}$ and detection limit as a function of a) $\mathrm{SO}_{2}$ flow 2 rate b) sample/sheath flow ratio, c) sample flow with fixed sample/sheath flow ratio, d) inlet and 3 sheath voltages difference, e) sheath voltage with fixed voltage difference between inlet and sheath 4 voltages, f) $\mathrm{N}_{2}$ buffer flow with the other parameters constant. The signal is normalized based on the 5 signal intensity at the settings of $5 \mathrm{sccm} \mathrm{SO}$, 16.8 slpm total flow, 12.6 slpm sheath flow, $3.7 \mathrm{slpm}$ 6 sample flow, $440 \mathrm{sccm} \mathrm{N}_{2}$ buffer flow, $-80 \mathrm{~V}$ sheath voltage, $-32 \mathrm{~V}$ inlet voltage, and $41 \%$ relative 7 humidity of the sample air. Red dashed lines highlight the optimized values selected for our CIMS.

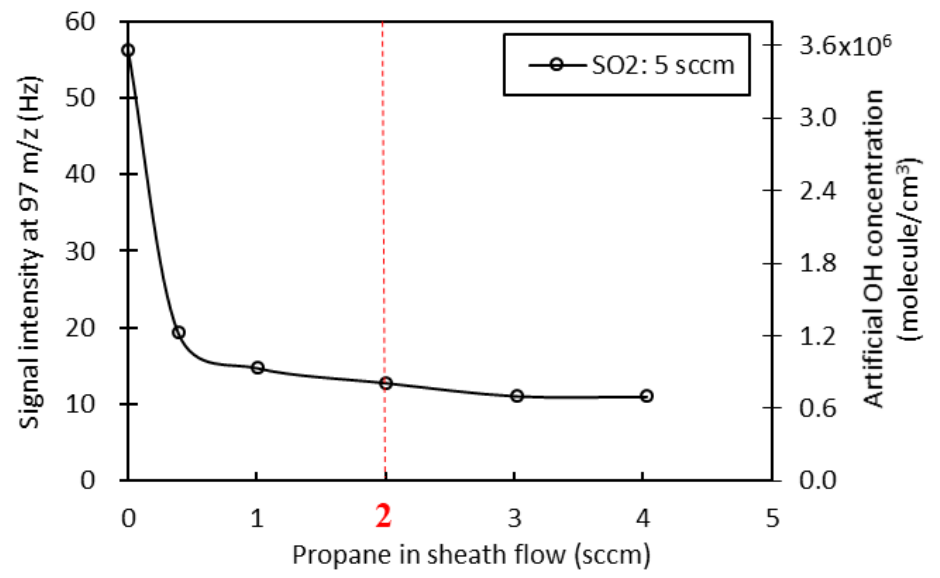

Figure 6. Artificial $\mathrm{OH}$ signal as a function of propane flow rate added in sheath flow. N2 gas was used as sample air so that there were no $\mathrm{OH}$ radicals in sample air. Red dashed line was the optimized flow rate applied for our CIMS.

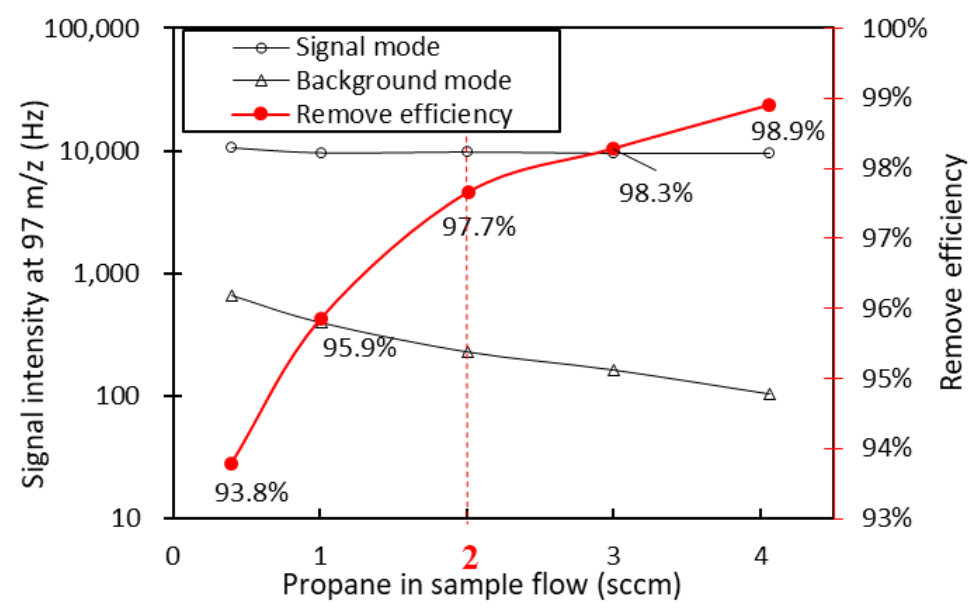

Figure 7. Signal intensity at $97 \mathrm{~m} / \mathrm{z}$ and $\mathrm{OH}$ remove efficiency as a function of propane flow rate added in the sample flow propane during the calibration experiment. The relative humidity of sample air was $41 \% . \mathrm{SO}_{2}$ flow rate was $5 \mathrm{sccm}$. Red dashed line highlights the optimized flow rate applied for our CIMS. 


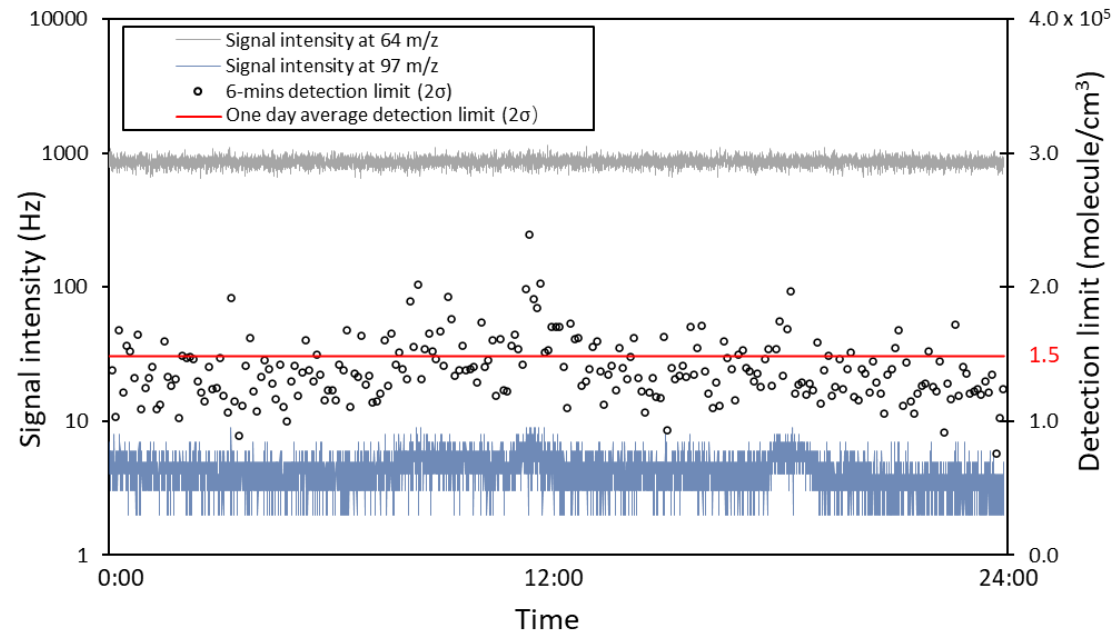

3 Figure 8. The detection limit $(2 \sigma)$ of the CIMS. One day averaged detection limit is $1.5 \times 10^{5}$ 4 molecule $/ \mathrm{cm}^{3}$.
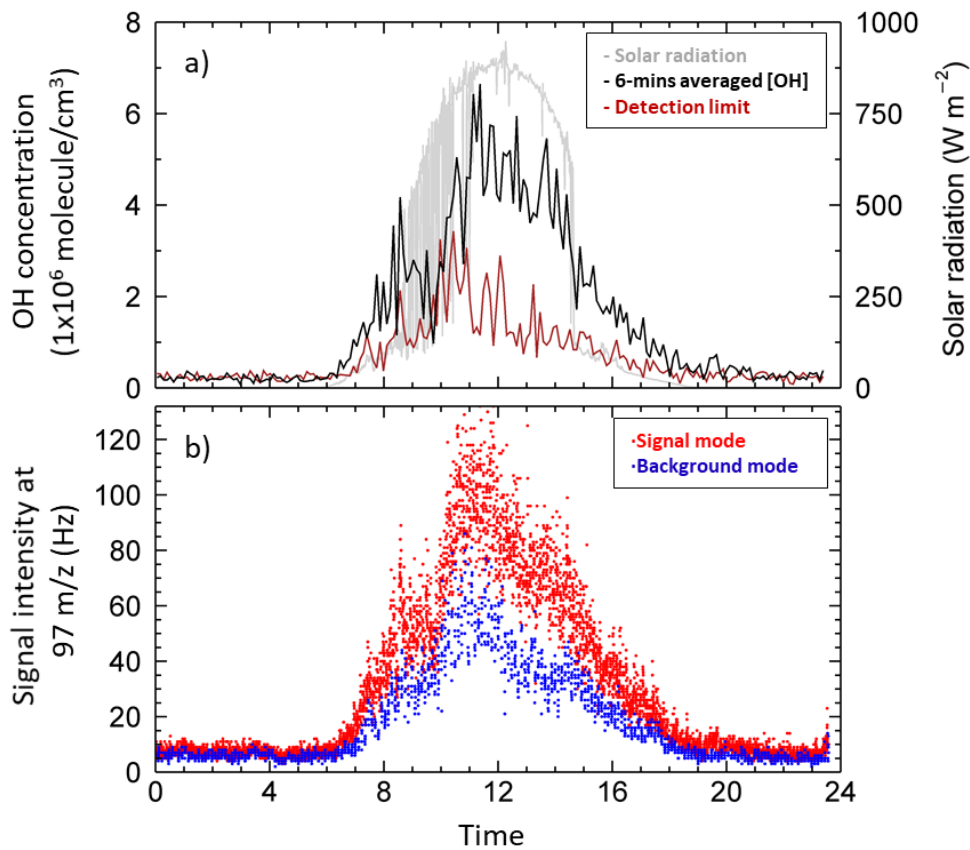

5

$6 \quad$ Figure 9. a) Diurnal variation of $\mathrm{OH}$ concentration and solar radiation on the 11th floor of a teaching 7 building on the campus of the Hong Kong Polytechnic University on April 25, 2019. b) The signal 8 intensity at $97 \mathrm{~m} / \mathrm{z}$ for two different measurement modes. 